
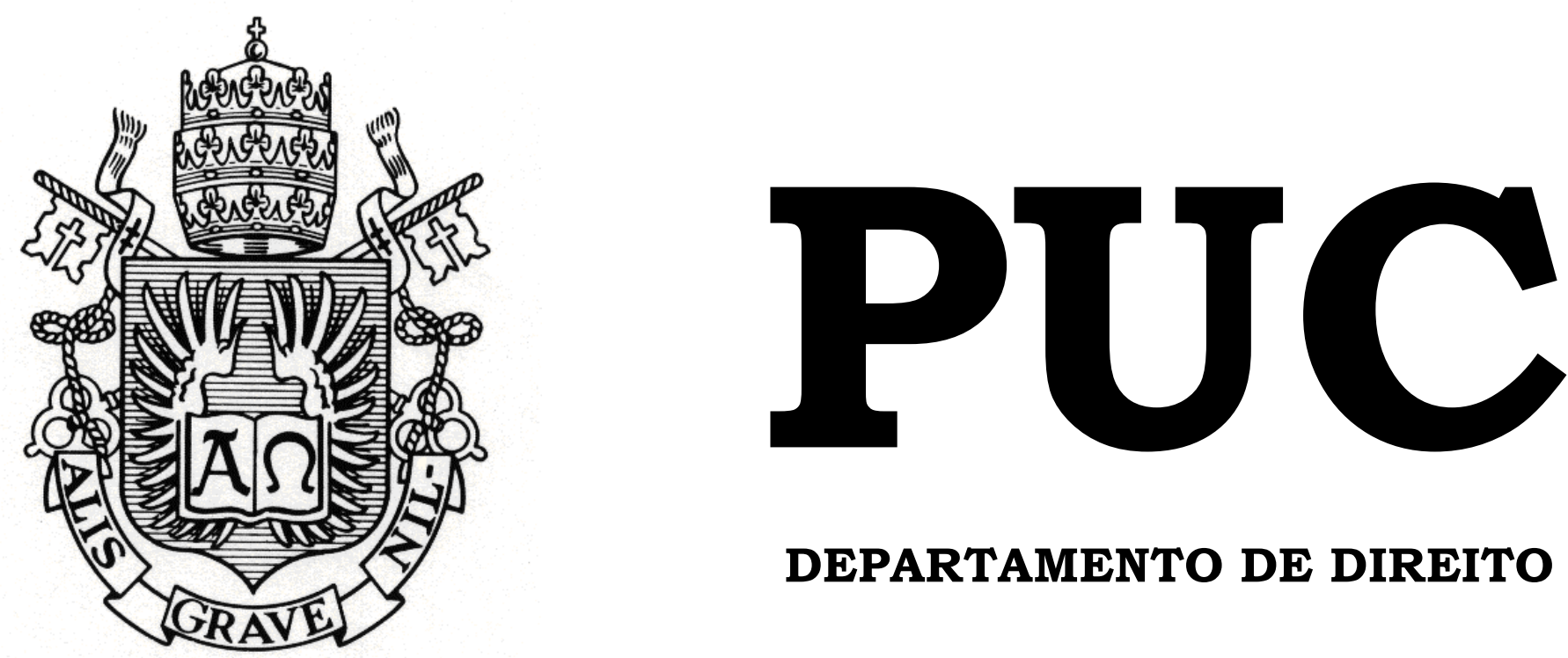

DEPARTAMENTO DE DIREITO

\title{
MANIPULAÇÃO DE MERCADO: ANÁLISE DA REPRESSÃO NAS ESFERAS ADMINISTRATIVA E PENAL
}

por

JÚLIA MIRANDA GOMES

ORIENTADORA: Norma Jonssen Parente 2018.2

PONTIFÍCIA UNIVERSIDADE CATÓLICA DO RIO DE JANEIRO RUA MARQUÊS DE SÃO VICENTE, 225 - CEP 22453-900 RIO DE JANEIRO - BRASIL 


\title{
MANIPULAÇÃO DE MERCADO: ANÁLISE DA REPRESSÃO NAS ESFERAS ADMINISTRATIVA E PENAL
}

\author{
por \\ JÚLIA MIRANDA GOMES
}

Monografia

apresentada

ao

Departamento de Direito da Pontifícia Universidade Católica do Rio de Janeiro (PUC-Rio) para a obtenção do Título de Bacharel em Direito.

Orientadora: Norma Jonssen Parente 


\section{Agradecimentos}

Agradeço a todos os meus amigos e familiares, que tanto me apoiaram nessa trajetória, trazendo leveza, palavras de carinho e conforto e compreensão nos momentos de ausência.

A meus pais, Eliane e Antônio Cláudio, o meu mais sincero agradecimento. Se aqui estou, é porque tive todo o apoio e amor possível. Obrigada por me incentivarem a sempre ir mais longe - com a certeza de um porto seguro em meio às incertezas da vida.

A meus avós, Maria e João, por serem meus exemplos de integridade e generosidade e eterna fonte de inspiração.

Por fim, agradeço a todos os professores que tive, pela contribuição imensurável na minha formação, não só acadêmica e profissional, mas também pessoal. 


\section{Resumo}

O presente trabalho tem o objetivo de analisar o ilícito da manipulação de mercado e a sua repressão na legislação brasileira. Para isso, estuda-se o delito tipificado no artigo $27-\mathrm{C}$ da Lei $6.385 / 76$, ponderando as mudanças trazidas pela Lei 13.506/2017, que retirou do tipo penal a finalidade de alterar artificialmente o regular funcionamento do mercado e, portanto, simplificou a comprovação do delito. Ademais, analisa-se os quatro ilícitos administrativos previstos na Instrução CVM 08/79 e a interação entre as duas esferas repressivas, administrativa e penal. Para uma melhor compreensão acerca do tema, visto a escassez de doutrina, realiza-se uma análise de julgados pela Comissão de Valores Mobiliários e pela Justiça Federal e uma comparação entre a legislação brasileira, a americana e a europeia em relação à manipulação de mercado. Por fim, conclui-se com comentários a possíveis modificações às leis e a importância da interação entre a Comissão de Valores Mobiliários e o Ministério Público Federal.

\section{Palavras-chave:}

Manipulação de Mercado - Mercado de Capitais - Mercado de Valores Mobiliários - Regulação - Processo Administrativo Sancionador - Proteção ao Investidor - Comissão de Valores Mobiliários - Instrução CVM 08/1979 


\section{Sumário}

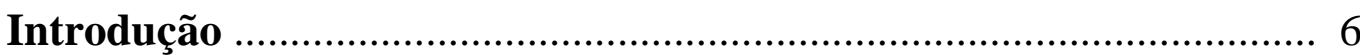

Capítulo 1 - Regulação do mercado de capitais .................................... 9

1.1. O Estado no domínio econômico ……………………………..... 9

1.2. A CVM e sua atuação regulatória ……………………………..... 11

1.3. O bem jurídico protegido .......................................................... 15

Capítulo 2 - Manipulação de mercado na legislação brasileira …....... 18

2.1. Manipulação de mercado no direito penal ..................................... 18

2.2. As mudanças da Lei 13.506/2017 .................................................. 22

2.3. Ilícitos administrativos da Instrução CVM n. ${ }^{\circ} 8 / 79$...................... 25

2.4. Interface entre as esferas administrativa e penal ........................... 31

Capítulo 3 - Manipulação de mercado em espécie ............................... 36

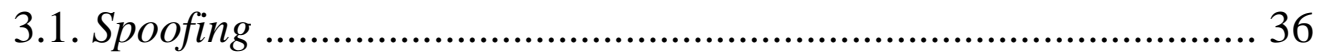

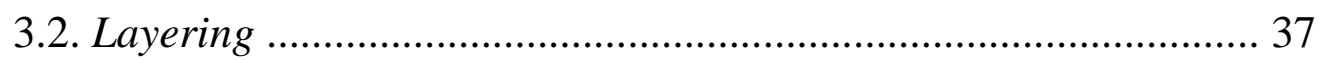

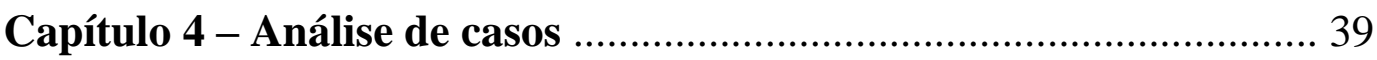

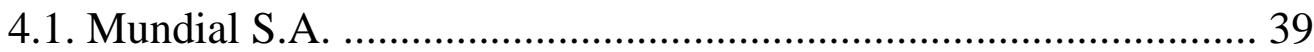

4.2. Companhia de Saneamento do Paraná S.A. (Sanepar) ................... 42

4.3. Paiffer Management Ltda. .......................................................... 43

Capítulo 5 - Manipulação de mercado no Direito Comparado .......... 46

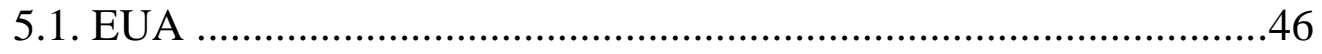

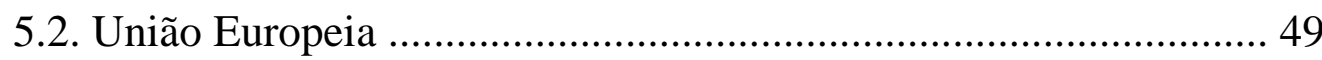

5.2.1. Regulamento UE n. ${ }^{\circ}$ 596/2014 _............................................. 49

5.2.2. Diretiva 2014/57/EU ............................................................ 51

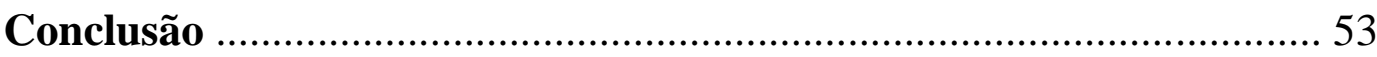

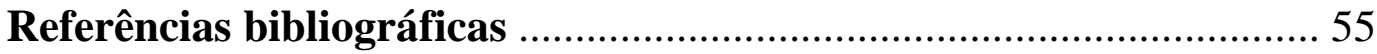




\section{Lista de abreviações}

CMN - Conselho Monetário Nacional

CVM - Comissão de Valores Mobiliários

ESMA - European Securities and Markets Authority

FCA - Financial Conduct Authority

ICVM - Instrução CVM

SEC - Securities and Exchange Comission

SMI - Superintendência de Relações com o Mercado e Intermediários 


\section{Introdução}

As oscilações dos preços no mercado de capitais cada vez mais fazem parte do senso comum. Se antes esse fenômeno era de conhecimento apenas dos profissionais de mercado, hoje, com o desenvolvimento dos meios de comunicação, as informações tornaram-se acessíveis à população. Com o advento da Internet, notícias e cotações de pregões circulam numa velocidade jamais imaginada e atingem um número irrestrito de pessoas.

Não obstante, jornais e sites possuem um espaço dedicado à economia, com comentários diários sobre o desempenho econômico do país e gráficos das cotações dos preços. Além disso, a negociação pode ser acompanhada online, com a participação de qualquer investidor na compra ou venda, no momento que achar conveniente.

Os preços são formados através das decisões dos investidores. Não existe mercado sem eles, as cotações se modificam a todo momento a partir do movimento dos investidores, influenciando-se de maneira recíproca. Mudanças na oferta ou na procura resultam na oscilação do preço: se a demanda aumenta e a oferta permanece constante, o preço sobe; quando a oferta aumenta e a demanda permanece constante, o preço cai. É assim o livre funcionamento do mercado.

Leslie Amendolara classifica como mercado perfeito:

“aquele em que preços necessariamente estarão sempre refletindo, naquele momento, a vontade dos investidores de comprar ou vender um valor mobiliário, segundo a lei da oferta e da procura, sem gozar de nenhuma informação privilegiada ou utilizar-se de manipulação". ${ }^{1}$

No entanto, dentre os incontáveis aspectos positivos, a rapidez de circulação e a facilidade de acesso à informação também geram impactos negativos, já que facilitam a prática de ilícitos que interferem no mercado perfeito. A prática de ilícitos contra o mercado de capitais é uma realidade

\footnotetext{
${ }^{1}$ AMENDOLARA, Leslie. Fundamentos e Objetivos da Regulamentação do Sistema de Informação de Sociedades que fazem Ofertas Públicas. In: VII Congresso Argentino de Derecho Societario y III Congresso Iberoamericano de Derecho Societario y de la Empresa. La Sociedad Comercial ante El tercer milênio, Buenos Aires, 1998. p. 6.
} 
criminal atual, inserida no que se convencionou designar por criminalidade econômica e interligada com a ideia do "crime de colarinho branco", introduzida em 1939 por Edwin H. Sutherland.

A repressão à manipulação de mercado é altamente relevante e necessária na regulação do mercado de capitais. A sua ocorrência pode desestruturar a credibilidade do mercado, uma vez que impede a eficiente transferência de recursos entre investidores, a partir da distorção de preços e volumes transacionados.

A identificação de falhas intrínsecas ao funcionamento do mercado de capitais que possibilitam a realização de manobras leva à adoção de medidas preventivas e sanções administrativas e penais a tais práticas.

Otavio Yazbek ensina que

"os meios peculiares para a proteção ao consumidor no mercado financeiro e de capitais estão relacionados não apenas à tutela das posições individuais, mas também à necessidade de garantir a confiabilidade dos mercados, sua estabilidade e eficiência [...]. Mais do que a qualidade do produto adquirido, não raro de difícil, senão impossível, reconhecimento a priori, cumpre garantir a legitimidade dos procedimentos adotados". ${ }^{2}$

Tendo em vista o potencial danoso da interferência ao regular funcionamento do mercado de capitais, o objetivo do presente trabalho é realizar uma análise sobre a manipulação de mercado e os mecanismos de repressão e combate a esse ilícito, um tema de suma importância para o mercado de capitais que carece de bibliografia e cuja jurisprudência ainda é escassa.

Partindo dessa introdução, que realizou considerações básicas em relação ao tema, o primeiro capítulo pretende abordar o papel do Estado como regulador no domínio econômico e a atuação da Comissão de Valores Mobiliários na regulação do mercado de capitais.

O segundo capítulo analisa o crime de manipulação de mercado tipificado no artigo $27-\mathrm{C}$ da Lei 6.385/76, discorrendo sobre as mudanças

\footnotetext{
${ }^{2}$ YAZBEK, Otávio. Regulação do mercado financeiro e de capitais. Rio de Janeiro: Elsevier, 2009. p. 225.
} 
trazidas pela Lei 13.506/2017, e a Instrução CVM n. ${ }^{\circ}$ 8/79. Por fim, aborda a interface entre as esferas administrativa e penal.

Em seguida, o terceiro capítulo discorre sobre o spoofing e layering, tipos de manipulação de mercado desenvolvidos a partir das novas tecnologias.

O quarto capítulo faz uma análise de casos relativos ao tema submetidos a julgamento pela CVM e pela Justiça Federal, a mostrar o entendimento atual sobre a manipulação de mercado.

Por fim, o quinto capítulo pretende trazer a perspectiva de outros sistemas jurídicos em relação à manipulação de mercado, examinando a legislação dos Estados Unidos, com foco na Securities Exchange Act; e da União Europeia, a partir da análise do Regulamento (UE) no. 596/2014 sobre abuso de mercado e da Diretiva 2014/57/UE. 


\section{Capítulo 1 - Regulação do mercado de capitais}

\subsection{O Estado no domínio econômico}

A Constituição Federal de 1988 estabelece, por meio dos seus princípios e regras, um limite de interpretação do Estado liberal e do Estado social.

Em um modelo liberal, cabe ao estado estabelecer regras gerais que garantam a liberdade dos agentes privados. A atividade econômica se fundamenta no conjunto de múltiplas relações que se estabelecem entre os milhares de agentes econômicos que se relacionam direta ou indiretamente no mercado.

Essa visão estritamente liberal do sistema econômico foi confrontada ao longo dos séculos XIX e XX. O surgimento da indústria promoveu, ao mesmo tempo, grande produção de riquezas e expressivos confrontos sociais, fazendo-se necessária uma atuação estatal para preservar o próprio sistema de mercado.

Com o tempo, o Estado foi assumindo determinados papéis, encarregando-se da promoção e defesa social, fornecendo serviços públicos e atuando na redução da desigualdade social. O chamado Estado de bem-estar social, portanto, caracteriza-se pela intervenção estatal na economia, antes livre à atuação dos particulares.

Assim, o Estado deixou de ter um papel exclusivamente neutro na economia. A autonomia privada se mantém, mas com o reconhecimento de que não é absoluta, pela existência de interesses coletivos que devem ser perseguidos através de atuação pública, incluindo a prestação de serviços públicos.

A Constituição brasileira reconhece a existência de interesses coletivos, como o direito a saúde, educação, trabalho, moradia, lazer, assim como estabelece um sistema de garantia de tais interesses. 
Nas últimas décadas, verificou-se a falência do Estado intervencionista e um movimento de desestatização. Surge, então, uma tendência da ascensão do Estado Regulador. Aos poucos, o papel de agente econômico é diluído para se centralizar em uma função regulatória.

Nesse modelo, o Estado continua sendo responsável pelos serviços públicos, mas, devido à crescente complexidade social e global e a necessidade de se diminuir os gastos da máquina estatal, a prestação desses serviços é delegada a agentes privados. Assim, adquire o Estado uma posição de atuação indireta na economia. Essa regulação se dá pelo condicionamento ou incentivo de determinados comportamentos por parte dos entes privados, incluindo também a fiscalização das condutas.

A atividade regulatória trata-se, portanto, de alguma forma de restrição estabelecida pelo Estado ao modo pelo qual os agentes privados vão exercer as suas atividades. A regra é a liberdade dos agentes econômicos.

Alexandre Santos de Aragão define a regulação como o conjunto de medidas legislativas, administrativas e convencionais, abstratas ou concretas, pelas quais o Estado, de maneira restritiva da liberdade privada ou meramente indutiva, determina, controla ou influencia o comportamento dos agentes econômicos, evitando que lesem os interesses sociais definidos no marco da Constituição e orientando-se em direções socialmente desejáveis. ${ }^{3}$

No entanto, a regulação passa a ser interpretada num sentido amplo, não incidindo somente nos serviços públicos, mas em setores da economia que possuem algum tipo de desequilíbrio, não sendo capaz de se autorregular.

Carlos Ari Sundfeld ensina que

"A regulação atinge tanto os agentes atuantes em setores ditos privados (o comércio, a indústria, os serviços comuns - enfim, as atividades econômicas em sentido estrito) como os que, estando especialmente habilitados, operam em áreas de reserva estatal (prestação de serviços públicos, exploração de bens públicos e de monopólios estatais)." ${ }^{\prime 4}$

\footnotetext{
${ }^{3}$ ARAGÃO, Alexandre Santos de. Agências Reguladoras e a Evolução do Direito Administrativo Econômico. Rio de Janeiro: Forense. 2002. p. 37.

${ }^{4}$ SUNDFELD, Carlos Ari. Direito Econômico Brasileiro, $1^{\mathrm{a}}$ ed., $2^{\mathrm{a}}$ tiragem. São Paulo: Malheiros. p. 18.
} 
Essa regulação econômica tem como objetivo prevenir práticas abusivas, garantir o acesso à informação por parte do consumidor e assegurar que a interação dentro do mercado ocorra de forma adequada e eficiente. Atua, assim, nas falhas de mercado.

Em meio ao novo cenário de atuação estatal, surgem as agências reguladoras. São figuras recentes no cenário da Administração Pública brasileira e têm como propósito a intervenção em mercados específicos.

No Brasil, as agências reguladoras foram instituídas como autarquias sob regime especial, que integram a Administração Indireta, vinculadas ao Ministério competente para atuar no respectivo mercado. São caracterizadas pela sua independência política, autonomia administrativa e financeira e prerrogativas de permanência no cargo de seus dirigentes.

A Constituição da República de 1988 sedimenta a intervenção do Estado no domínio econômico com uma atuação regulatória e fiscalizatória em relação ao mercado de valores mobiliários, a fim de compatibilizar o princípio da liberdade econômica e da livre iniciativa com a necessária defesa dos direitos e interesses sociais.

A Comissão de Valores Mobiliários (CVM) é a agência reguladora que disciplina, fiscaliza e desenvolve o mercado de capitais, tema que será desenvolvido a seguir.

\subsection{A CVM e sua atuação regulatória}

A Comissão de Valores Mobiliários foi criada pela Lei 6.385/76, à semelhança da Securities Exchange Comission (SEC), com a finalidade de disciplinar, fiscalizar e desenvolver o mercado de valores mobiliários. Assim, é dotada dos poderes de normatização o mercado de capitais, de fiscalização permanentemente e de aplicação sanções administrativas aos infratores. ${ }^{5}$

\footnotetext{
${ }^{5}$ CARVALHOSA, Modesto; EIZIRIK, Nelson. A nova Lei das sociedades anônimas. São Paulo:
} Saraiva, 2002. p. 441. 
Somente adquiriu a condição de entidade autárquica em 2001, a partir da reforma do mercado de capitais, instituída pela Lei n. ${ }^{\circ}$ 10.303/2001, assim como a Medida Provisória n. ${ }^{\circ} 8$ de 31 de outubro de 2001 (convertida na Lei 10.411/2002) e o Decreto n. 3.995 de 31 de outubro de 2001.

É uma autarquia federal, vinculada ao Ministério da Fazenda, com personalidade jurídica e patrimônio próprios, dotada de autoridade administrativa independente, ausência de subordinação hierárquica, mandato fixo e estabilidade de seus dirigentes, e autonomia financeira e orçamentária, nos termos da atual redação do artigo $5^{\circ}$ da Lei 6.385/76.

Acima da autarquia se encontra o Conselho Monetário Nacional (CMN), que compõe o Sistema Financeiro Nacional, e é o órgão superior cuja responsabilidade é formular a política da moeda e do crédito, visando a estabilidade da moeda e o desenvolvimento econômico e social do País.

Segundo Júlio Ramalho Dubeux, a independência dos dirigentes tem significativa importância no sentido de barrar eventuais pressões dos setores econômicos regulados, cujos atores muitas vezes são hábeis em pressionar o Poder Executivo com vistas à troca de dirigentes das autarquias, especialmente quando veem seus interesses serem contrariados. A independência conferida aos dirigentes, por conseguinte, aponta para ambos os sentidos, seja em relação ao Poder Executivo, seja em relação aos administrados regulados. ${ }^{6}$

À CVM também foi atribuída a responsabilidade de assegurar o acesso do público às informações relativas às companhias emissoras e aos valores mobiliários que serão negociados, o chamado disclosure, promovendo a transparência dentro do mercado de capitais.

A atribuição de órgão fiscalizador concede à CVM o poder para examinar e extrair cópias de demonstrações e registros contáveis, livros, documentos, programas eletrônicos, arquivos magnéticos, ópticos e de qualquer outra natureza dos participantes do mercado, como instituições

\footnotetext{
${ }^{6}$ DUBEUX, Julio Ramalho. A Comissão de Valores Mobiliários e os principais instrumentos regulatórios do mercado de capitais brasileiro. Porto Alegre: Sergio Antonio Fabris, 2006. p. 36.
} 
financeiras, companhias emissoras, corretoras e entidades de mercado de balcão. No mais, pode convocar pessoas para prestação de informações ou esclarecimentos, além de requisitar informações de órgãos públicos.

A atividade fiscalizatória não deixa de ser uma atuação preventiva no cometimento de ilícitos. A autarquia tem a faculdade de proibir atos e práticas que considere danosas ao mercado, além de decretar o recesso de bolsas de valores, proceder ao cancelamento de registros e, por fim, suspender de negociação. Essa última é um grande instrumento de prevenção da manipulação do mercado, impedindo a sua materialização. ${ }^{7}$

Ainda, a referida lei ofereceu à CVM os meios materiais e institucionais necessários ao cumprimento de sua missão, notadamente: o poder normativo, através do qual a CVM regula a atuação dos diversos agentes do mercado; e o poder punitivo, através do qual, assegurado o direito de ampla defesa, permite a penalização de quem descumpre as normas baixadas pelo órgão ou de quem pratica atos fraudulentos no mercado. ${ }^{8}$

Assim, a CVM tem o poder de conduzir os processos administrativos sancionadores. Instaurado o procedimento para apurar as irregularidades, o acusado tem assegurado o seu amplo direito de defesa. O Direito Administrativo Sancionador, como desdobramento do Direito Punitivo, encontra-se subordinado ao princípio da legalidade das infrações e das penas. ${ }^{9}$

\section{Com efeito,}

"No mercado de capitais, as sanções administrativas ostentam força inquestionável, já que, ao contrário do que ocorre com as sanções penais, são imponíveis diretamente pelo órgão regulador (CVM) e com especial celeridade. No caso, a Administração Pública está dotada de plenos poderes para, de acordo com a necessidade ou utilidade, intimidar e, principalmente, orientar os participantes do mercado na direção desejada". ${ }^{10}$

\footnotetext{
7 Art. $9 \S 1^{\circ}$, IV, da Lei 6.385/76.

${ }^{8}$ COMISSÃO DE VALORES MOBILIÁRIOS. $O$ mercado de valores mobiliários brasileiro. $3^{\mathrm{a}} \mathrm{ed}$. Rio de Janeiro: Comissão de Valores Mobiliários. p. 61.

${ }^{9}$ SANTOS, Alexandre Pinheiro dos; WELLISCH, Julya Sotto Mayor; BARROS, José Eduardo Guimarães. Mercado de Capitais. São Paulo: Saraiva, 2012. p. 48

${ }^{10}$ SANTOS, Alexandre Pinheiro dos; WELLISCH, Julya Sotto Mayor; BARROS, José Eduardo Guimarães. Op. cit., p. 42.
} 
Após constatada, em processo administrativo, a prática de irregularidades, podem ser aplicadas uma série de penalidades, advertência, multa, suspensão ou inabilitação para o exercício do cargo e suspensão ou cassação da autorização ou do registro, além da proibição temporária por prazo determinado da atuação de investidor e da prática de operações por parte dos integrantes do sistema de distribuição. ${ }^{11}$

A sanção pecuniária somente é aplicada nos casos de infração grave, e deve observar os limites máximos estabelecidos na lei. Até 2017, esse limite consistia em (i) quinhentos mil reais, (ii) $50 \%$ do valor da emissão ou operação irregular e (iii) três vezes o montante da vantagem econômica obtida ou da perda evitada em decorrência do ilícito. Com a reforma instituída pela Lei 13.506/2017, o valor máximo aumentou para cinquenta milhões de reais e adicionou-se a possibilidade de ser fixada pelo dobro do prejuízo causado aos investidores em decorrência do ilícito. $\mathrm{O}$ aumento do valor representa uma grande conquista para a autarquia, uma vez que o limite anterior não se mostrava suficiente para inibir o cometimento de ilícitos por parte de grandes companhias.

Ressalta-se a não previsão de uma sanção específica para cada infração, o que confere maior flexibilidade à entidade reguladora, o que coincide com a própria natureza do processo administrativo, marcantemente menos rígido do que o processo penal ou o processo civil. Nesse sentido, a possibilidade cumulação de sanções ajuda a CVM a encontrar a penalidade correta para a boa regulação do mercado. Naturalmente, a aplicação de qualquer sanção deve ser devidamente fundamentada e observando um critério de proporcionalidade.

Os recursos são interpostos ao Conselho de Recursos do Sistema Financeiro Nacional, o órgão julgador em última instância das decisões proferidas pela CVM nos processos administrativos, vinculado ao CMN e conhecido por "conselhinho".

\footnotetext{
${ }^{11}$ Art. 11, da Lei 6.385/76.
} 
Por fim, é essencial para a atuação da autarquia uma compreensão acerca dos valores mobiliários. Em 1976, a Lei 6.385 também conceituou valor mobiliário, mas de forma bastante restritiva. Ao longo dos anos, começou a se mostrar ineficiente perante o crescente desenvolvimento do mercado de capitais e inserção de novos produtos financeiros. O mercado evolui junto com a sociedade, pois nada mais é do que um reflexo dela.

Assim, a reforma da Lei 10.303/2001 ampliou o conceito de valores mobiliários, na redação do art. $2^{\circ}$ da Lei 6.385/1976 que vigora atualmente, a saber:

(i) as ações, debêntures e bônus de subscrição;

(ii) os cupons, direitos, recibos de subscrição e certificados de desdobramento relativos aos valores mobiliários referidos no inciso II;

(iii) os certificados de depósito de valores mobiliários;

(iv) as cédulas de debêntures;

(v) as cotas de fundos de investimento em valores mobiliários ou de clubes de investimento em quaisquer ativos;

(vi) as notas comerciais;

(vii) os contratos futuros, de opções e outros derivativos, cujos ativos subjacentes sejam valores mobiliários;

(viii) outros contratos derivativos, independentemente dos ativos subjacentes; e

(ix) quando ofertados publicamente, quaisquer outros títulos ou contratos de investimento coletivo, que gerem direito de participação, de parceria ou de remuneração, inclusive resultante de prestação de serviços, cujos rendimentos advêm do esforço do empreendedor ou de terceiros.

A Lei expressamente excluiu do rol os títulos da dívida pública federal, estadual ou municipal e os títulos cambiais de responsabilidade de instituição financeira, exceto as debêntures, explicitando que tais títulos não estão sob a tutela da CVM.

\subsection{O bem jurídico protegido}

Segundo Siegfried Kumpel, o bem jurídico protegido pelo interesse público estatal para a existência e manutenção de um mercado eficiente é a capacidade funcional do mercado de capitais. Essa capacidade seria necessária para que os diversos segmentos do mercado possam realizar, de forma eficiente, todas as funções a eles atribuídas. Divide-se em três 
aspectos: (i) capacidade funcional institucional, (ii) capacidade funcional operacional e (iii) capacidade funcional alocativa. ${ }^{12}$

De acordo com o autor alemão, a primeira delas consiste no conjunto de condições básicas para a existência de mecanismos eficientes nos diversos segmentos de mercado, como, o dever de tratamento igualitário ou equitativo, a transparência de informações, a existência de regras de conduta para intermediários, a defesa dos direitos e interesses de investidores e a existência de efetiva fiscalização estatal.

A capacidade funcional operacional seria o poder de atrair recursos para o mercado de valores mobiliários a partir da manutenção dos custos de emissão e negociação no menor valor possível.

Por fim, a capacidade funcional alocativa está ligada à eficiência com que o mercado de capitais administra os recursos disponíveis para os maiores rendimentos com o menor risco possível. O funcionamento do mercado, então, deve garantir que as poupanças se dirijam naturalmente às unidades produtivas que apresentem maior rentabilidade, entre as de mesmo nível de risco.

A manipulação de mercado, portanto, afeta essa capacidade funcional alocativa, atingindo diretamente o regular funcionamento do mercado, impedindo que os preços dos valores mobiliários sejam formados unicamente pela livre oferta e procura, refletindo todas as informações disponíveis sobre os ativos e a companhias emissoras.

Nesse sentido, Norma Parente explica:

“(...) o mercado eficiente promove a alocação eficaz da poupança no setor produtivo e consequentemente o crescimento econômico. As forças espontâneas do mercado e a soma dos interesses privados, porém, nem sempre são suficientes para assegurar o funcionamento regular do mercado. Daí surge a necessidade de intervenção regulatória". ${ }^{13}$

\footnotetext{
12 KUMPEL, Siegfried. Direito do mercado de capitais - do ponto de vista do direito europeu, alemão e brasileiro. Rio de Janeiro: Renovar, 2007, p. 22.

${ }^{13}$ PARENTE, Norma. A Regulação e o desenvolvimento do Mercado de Capitais. Revista de Direito Bancário do Mercado de Capitais e da Arbitragem. São Paulo: Revista dos Tribunais, n. ${ }^{\circ}$ 18, outdez/2002. p. 247.
} 
Acrescenta-se que a alteração do regular funcionamento do mercado, evidentemente, pode diminuir a confiança do investidor, que é peça essencial para que o mercado mantenha sua integridade. A repressão a práticas ilícitas, através da aplicação de sanções, é o que restaura a confiabilidade no mercado eficiente, apontando, mais uma vez, para a imprescindibilidade da regulação. A manipulação de mercado caracteriza tipicamente um processo de formação artificial de preços, um falso "mercado" e, consequentemente, agride o funcionamento regular do mercado de capitais. ${ }^{14}$ Seria, portanto, uma adoção de práticas que visam alterar a lei natural da oferta e demanda. Essencialmente, trata-se da interferência intencional nas forças livres da oferta e procura no mercado de valores mobiliários.

${ }^{14}$ CARVALHOSA Modesto; EIZIRIK, Nelson. Op. cit., p. 534. 


\section{Capítulo 2 - Manipulação de Mercado na legislação brasileira}

\subsection{Manipulação de mercado no Direito Penal}

A manipulação do mercado de ações é uma prática antiga, datada do século XIX. Em 1814, na Inglaterra, já havia uma condenação no caso Rex v. de Berenger, por rumores baseados sobre a morte de Napoleão. ${ }^{15}$

No Brasil, a Lei n. ${ }^{o} 3.150 / 1882$, em seu artigo $27 \S 3^{\circ}$, já criminalizava a conduta dos administradores que, por qualquer artifício, promovessem falsas cotações das ações.

Em 1940, na edição do Código Penal atual, o artigo 177, § $1^{\circ}$ inciso II, previu punições para "o diretor, o gerente ou o fiscal que promove, por qualquer artifício, falsa cotação das ações ou de outros títulos da sociedade".

A Lei dos Crimes contra a Economia Popular (Lei n. ${ }^{\circ}$ 1.521/1951) continha em seu artigo $3^{\circ}$, inciso VI, o crime de "provocar a alta ou baixa de preços de mercadorias, títulos públicos, valores ou salários por meio de notícias falsas, operações fictícias ou qualquer outro artifício”.

Segundo Cezar Roberto Bittencourt, esse delito nunca foi efetivamente punido no país, principalmente pela dificuldade de detectar essa sutil forma de manipulação. ${ }^{16}$

A tipificação do crime de manipulação de mercado se deu somente no ano de 2001, a partir da reforma do mercado de capitais feita pela Lei 10.303/01, que acrescentou o Capítulo VII-B, que disciplina os crimes contra o mercado de capitais. Foram inseridos, assim, os artigos 27-C, 27-D, 27-E e 27-F à lei 6.385/76.

À época, a redação do artigo 27-C, que tipifica a manipulação de mercado, era a seguinte:

"Realizar operações simuladas ou executar outras manobras fraudulentas, com a

finalidade de alterar artificialmente o regular funcionamento dos mercados

\footnotetext{
${ }^{15}$ VEIGA, Alexandre Brandão da. Crime de manipulação, defesa e criação de mercado. Coimbra: Almedina, 2001. p. 17.

${ }^{16}$ BITTENCOURT, Cezar Roberto. Tratado de direito penal econômico. São Paulo: Saraiva, vol. I, 2016. p. 148 .
} 
de valores mobiliários em bolsa de valores, de mercadorias e de futuros, no mercado de balcão ou no mercado de balcão organizado, com o fim de obter vantagem indevida ou lucro, para si ou para outrem, ou causar dano a terceiros: Pena - reclusão, de 1 (um) a 8 (oito) anos, e multa de até 3 (três) vezes o montante da vantagem ilícita obtida em decorrência do crime."

Modesto Carvalhosa e Nelson Eizirik criticam a incriminação das condutas, apontando para a redação das normas:

“... são elas extremamente imprecisas, fundadas em standards, cujo conteúdo somente poderá ser preenchido mediante a aplicação de disposições legais ou regulamentares do mercado de capitais, estranhas ao Direito Penal". ${ }^{17}$

Além disso, atentam para a pouca familiarização dos aplicadores da Lei n. ${ }^{\circ}$ 10.303/2001 com o direito societário e com a disciplina legal do mercado de valores mobiliários.

Sobre a previsão de pena privativa de liberdade, Heleno Cláudio Fragoso afirma que é consenso, na doutrina contemporânea do Direito Penal, que a prisão deve ser utilizada o menos possível, apenas como último recurso. ${ }^{18}$

Em 2017, a Lei 13.506 alterou a tipificação do art. 27-C, fato que será aprofundado no item seguinte, fixando a seguinte redação:

"Realizar operações simuladas ou executar outras manobras fraudulentas destinadas a elevar, manter ou baixar a cotação, o preço ou o volume negociado de um valor mobiliário, com o fim de obter vantagem indevida ou lucro, para si ou para outrem, ou causar dano a terceiros:

Pena - reclusão, de 1 (um) a 8 (oito) anos, e multa de até 3 (três) vezes o montante da vantagem ilícita obtida em decorrência do crime."

A conduta incriminada constitui ofensa a um bem jurídico juridicamente protegido, no caso, a estabilidade do mercado de capitais.

Baltazar Junior ensina:

“A norma penal visa proteger, como bem jurídico, o regular funcionamento do mercado de valores mobiliários e o processo de formação de preços, especialmente no mercado secundário, onde ocorrem negociações de títulos entre investidores, após sua emissão pela Companhia". ${ }^{19}$

Avaliando o tipo objetivo, o núcleo da norma está contido em duas expressões: (i) realizar operações simuladas e (ii) executar outras manobras

\footnotetext{
${ }^{17}$ CARVALHOSA Modesto; EIZIRIK, Nelson. Op. cit., p. 531.

${ }^{18}$ FRAGOSO, Heleno Cláudio. Lições de Direito Penal: a Nova Parte Geral. $11^{\mathrm{a}}$ ed., revista por Fernando Fragoso, Rio de Janeiro, Forense, 1987. p. 301.

${ }^{19}$ BALTAZAR JUNIOR, José Paulo. Crimes Federais. São Paulo: Saraiva, 10a edição, 2015, p. $565-566$
} 
fraudulentas. Dessa forma, a simulação ou a fraude são elementos essenciais do tipo penal, sem os quais não se configura o crime.

Alexandre Brandão da Veiga delimita o conceito de operações para efeitos da manipulação de mercado em três grupos: ${ }^{20}$

O primeiro grupo seriam as chamadas operações por natureza, "negócios transmissivos de valores mobiliários ou instrumentos financeiros". Em segundo plano, os "negócios criadores de instrumentos financeiros", realizados fora do mercado organizado, como os empréstimos, mas convolados em operações pela sua imputação em mercado. Por fim, o autor aponta as "operações realizadas em mercado organizado como tal qualificadas por Lei”.

Somente as operações concluídas devem ser levadas em conta, excluindo-se as ofertas, propostas negociais que não lograram êxito e todos os atos preliminares à celebração negocial. As operações não são, portanto, fictícias, irreais, mas se tratam de negócios efetivamente realizados, com transferência de titularidade e capital. Deve haver a real possibilidade de um dano concreto, não se configurando o crime nos casos em que a conduta não for capaz de o fazer.

A simulação, por sua vez, seria um disfarce, uma tentativa de criar uma aparência verdadeira a uma situação falsa, com a pretensão de enganar terceiros. Frederico de Lacerda da Costa Pinto ensina:

\footnotetext{
"o que está em causa nos negócios de natureza fictícia não é, evidentemente, a sua existência real, mas seu significado. (...) a manipulação só surge como uma prática lesiva para o mercado e para os investidores porque os negócios celebrados existem efetivamente, mas não significam aquilo que aparentam". ${ }^{21}$
}

No tocante às manobras fraudulentas, Homero Prates classifica como ato fraudulento aquele que consiste na violação dos direitos de outra parte ou da lei, que não necessariamente contradiz as palavras da lei, dando mesmo a

\footnotetext{
${ }^{20}$ VEIGA, Alexandre Brandão da. Op. cit., p. 49-50

${ }^{21}$ PINTO, Frederico de Lacerda da Costa. O novo regime de crimes e contra-ordenações no código dos valores mobiliários. Coimbra: Almedina, 2000. p. 88.
} 
impressão de que as observa, quando, na realidade, as infringe, indo contra o sentido que as ditou. ${ }^{22}$

Trata-se do artifício ardiloso por meio do qual se busca forjar uma aparência falsa de realidade. É visível, portanto, a semelhança entre simulação e fraude, podendo-se até mesmo afirmar que a simulação seria englobada pela definição de fraude.

Essas condutas têm por objetivo induzir terceiros em erro dentro do mercado secundário de valores mobiliários, devendo ser efetivamente aptas a ludibriar e afetar o mercado, configurando crime impossível no caso de absoluta ineficácia do meio, de acordo com o artigo 17 do Código Penal. ${ }^{23}$

Assim como, naturalmente, não há crime se a variação de preços decorrer de fatores próprios do mercado, como a maior oferta ou procura por determinado ativo não provocada artificialmente, mas pela fusão ou incorporação de companhias, alterações legislativas ou mero reflexo da atuação das companhias.

O crime de manipulação de mercado, portanto, abrange condutas que se traduzem em operações aparentemente regulares, mas que, na realidade, são controladas pelos agentes de forma a violar o livre jogo da oferta e da procura. ${ }^{24}$

Apesar da possibilidade de interpretação extensa pela amplitude das condutas descritas na lei, ressalta-se a falta de previsão expressa de formas de manipulação presentes nos demais países que criminalizam a manipulação de mercado, como a realizada através de difusão de informações falsas.

\footnotetext{
22 PRATES, Homero. Atos simulados e atos em fraude à lei. São Paulo: Freitas Bastos. p. 310.

23 Art. 17: Não se pune a tentativa quando, por ineficácia absoluta do meio ou por absoluta impropriedade do objeto, é impossível consumar-se o crime.

${ }^{24}$ PINTO, Frederico de Lacerda da Costa. Op. cit., p 87.
} 


\subsection{As mudanças da Lei $13.506 / 2017$}

Em 13 de novembro de 2017, foi promulgada lei sobre o processo administrativo sancionador na esfera de atuação do Banco Central do Brasil e da Comissão de Valores Mobiliários.

Com o advento da Lei 13.506/2017, a estrutura dos tipos penais da Lei 6.385/76 foi alterada, afetando, assim, diretamente os processos penais no âmbito do mercado de capitais. A lei simplificou a estrutura dos crimes de manipulação de mercado e insider trading, o que acaba por expandir a sua abrangência. ${ }^{25}$ Como o objeto de estudo desse trabalho consiste na manipulação de mercado, serão abordados somente os aspectos relativos a esse delito.

A mudança no delito de manipulação de mercado consistiu em retirar do tipo penal a finalidade específica de "alterar artificialmente o regular funcionamento dos mercados de valores mobiliários em bolsa de valores, de mercadorias e de futuros, no mercado de balcão ou no mercado de balcão organizado". A nova redação prevê que as condutas devem ser "destinadas a elevar, manter ou baixar a cotação, o preço ou o volume negociado de um valor mobiliário".

Como visto anteriormente, o tipo penal anterior havia sido inserido no ordenamento jurídico brasileiro somente 16 anos antes. A efetiva repressão dos ilícitos penais no mercado de capitais é muito recente no ordenamento jurídico brasileiro, sendo a primeira condenação penal por manipulação de mercado somente em 2014, envolvendo negociações com ações de emissão da Companhia Rimet Empreendimentos Industriais e Comerciais S.A.

Assim, se evidencia uma escassez de jurisprudência em relação ao tema, o que impede uma avaliação clara sobre a necessidade de mudanças na lei. Ao mesmo tempo, essa escassez pode ser um indicador de falta de eficácia na redação do tipo penal e dificuldade na sua aplicação.

\footnotetext{
${ }^{25}$ SIMÕES, Pedro. Insider trading e crime de manipulação de mercado: reflexos da nova lei. Disponível em <https://www.jota.info/opiniao-e-analise/artigos/insider-trading-e-crime-demanipulacao-de-mercado-reflexos-da-nova-lei-27012018>. Acesso em 18/11/2018.
} 
Segundo Norma Parente, a modificação tornou a prova mais simples e facilitada, bastando circunscrever-se a apenas um único valor mobiliário, tornando-se desnecessário comprovar que houve alteração no funcionamento do mercado de valores mobiliários. ${ }^{26}$

O tipo penal do delito de manipulação de mercado evidencia a presença do dolo. O legislador optou por manter o trecho "com o fim de obter vantagem indevida ou lucro, para si ou para outrem, ou causar dano a terceiros."

Deve o agente, portanto, ter consciência da conduta e do resultado, da relação causal objetiva entre ambos e a vontade de realizar a conduta e produzir o resultado. Essa vontade pode se manifestar com a mera aceitação do resultado, o que configura o dolo eventual. ${ }^{27}$

Até a nova redação de 2017, o delito da manipulação de mercado possuía duplo elemento subjetivo. Era preciso comprovar a finalidade dolosa de alterar artificialmente o funcionamento do mercado. Com a alteração, essa comprovação tornou-se desnecessária, mas o tipo penal manteve um elemento subjetivo.

Dessa forma, o dolo específico ainda se faz presente, devendo ser demonstrado que a conduta do agente tinha o intuito de modificar ou manter o preço de determinado valor mobiliário especificamente para obtenção de vantagem, ou lucro, para si ou para outrem, ou de causar dano a terceiro.

No entanto, após previsão semelhante ser retirada da legislação portuguesa, Frederico de Lacerda da Costa Pinto defendeu que "o elemento subjetivo especial reportado à intenção de obter um benefício ou causar um prejuízo era, na verdade, desnecessário, probatoriamente complexo e inadequado à natureza econômica da incriminação". ${ }^{28}$

Ao mesmo passo, Fausto Martin de Sanctis discorre:

\footnotetext{
26 PARENTE, Norma. Tratado de Direito Empresarial. Vol. 6. Rio de Janeiro: Revista dos Tribunais, 2018. p. 678.

27 JESUS, Damásio E. de. Código Penal anotado, São Paulo, Saraiva, 2000. p. 68.

${ }^{28}$ PINTO, Frederico de Lacerda da Costa. Op. cit., p. 84.
} 
"essa última finalidade, creio, s.m.j., ser uma redundância do legislador, pois não seria possível cogitar de fraude sem o intuito de prejudicar terceiros com a obtenção de vantagem indevida". ${ }^{29}$

Por ser uma mudança extremamente recente, percebe-se, naturalmente, a escassez de doutrina em relação à repercussão da nova redação. No entanto, o ato de manipular, de realizar uma fraude ou operação simulada já contém em si, pela sua própria definição, a motivação de obter uma vantagem que, em circunstâncias normais, não ocorreria.

Assim, com a nova redação do artigo, a comprovação da conduta por si só indicaria a presença do dolo. Em um mercado onde se verifica que a manipulação vem, em sua maior parte, de agentes altamente qualificados e que desenvolvem elaborados mecanismos para obter vantagem ilícita, a complexidade comprobatória pode representar óbice à aplicação da lei de forma eficaz.

O crime permanece sendo formal e de perigo abstrato, consumandose com a prática de qualquer das condutas mencionadas no tipo penal, não sendo necessária a obtenção de resultado, desde que a atuação seja direcionada para manipular o mercado.

Tereza Beleza ensina:

“(...) o perigo aqui criado é um perigo ainda abstrato, não está concretizado sobre certo bem jurídico (...) é criado um perigo ainda não individualizado em qualquer vítima ou ofendido possível, ou em qualquer bem". ${ }^{30}$

De todo modo, nem toda ação que provoque alteração na cotação de ativos é delituosa. O exemplo de Modesto Carvalhosa e Nelson Eizirik ilustra essa hipótese:

“... se o agente negocia uma grande quantidade de títulos, num pequeno período de tempo, pode provocar a alteração da cotação de tais valores, sem a intenção de manipular; é o que ocorre nas operações que, por seu volume, causam um 'impacto de mercado', que não se confunde com a manipulação". ${ }^{31}$

\footnotetext{
29 SANCTIS, Fausto Martin de. Punibilidade no Sistema Financeiro Nacional: Tipos penais que tutelam o sistema financeiro nacional, incluindo o mercado de capitais. Campinas: Millennium, 2003, p. 98.

${ }^{30}$ BELEZA, Teresa, Direito Penal, 2. ${ }^{\circ}$ Vol. Lisboa: AAFDL, 1983. p. 127.

${ }^{31}$ CARVALHOSA Modesto; EIZIRIK, Nelson. Op. cit., p. 539
} 
Todavia, essa hipótese dificilmente ocorrerá, uma vez que os chamados block trades ocorrem em sua maioria sob forma de leilão, com a prévia notificação da intenção da venda do grande volume de ativos.

Destaca-se que a lei não modificou a previsão da pena, que permanece de um a oito anos, o que deixa uma margem enorme ao juiz para fixação da pena, uma vez que a pena máxima cominada é oito vezes maior do que a mínima.

\subsection{Ilícitos administrativos da Instrução CVM n.. 8/79}

A Lei 6.385/76 conferiu à CVM competência para definir as práticas vedadas aos participantes do mercado, visando resguardar a necessária confiabilidade do mercado de valores mobiliários.

A repressão às condutas que são capazes de alterar o regular funcionamento do mercado é fundamental. Alexandre Pinheiro dos Santos, Fábio Medina Osório e Julya Sotto Mayor Wellisch ensinam que a proteção estatal contra fraudes no mercado financeiro garante a confiabilidade necessária para a existência e o desenvolvimento desse mercado, que somente cumprirá a sua função alocativa com eficiência se todos os participantes puderem confiar no seu funcionamento transparente, seguro, impessoal e equânime, com igualdade de acesso a informações, assim como em um sistema eficaz de repressão aos desvios de conduta perpetrados. ${ }^{32}$

Assim, a CVM editou a Instrução n. ${ }^{\circ}$ 8/79 (ICVM 8/79) como a primeira manifestação de sua atividade regulatória no mercado de capitais. A instrução propositalmente conceituou de forma genérica o conjunto de práticas passíveis de sanção, o que dá ensejo a ampla interpretação, devendo a sua aplicação ser feita de acordo com o caso concreto. Esse caráter genérico se adequa ao dinamismo e mutabilidade intrínsecos a tais condutas, que acompanham o desenvolvimento tecnológico. A ICVM 8/79 aplica-se, hoje,

\footnotetext{
32 SANTOS, Alexandre Pinheiro dos; WELLISCH, Julya Sotto Mayor; BARROS, José Eduardo Guimarães. Op. cit., p. 106.
} 
às mais diversas situações fáticas, como a prática do spoofing, modalidade de manipulação com uso de robôs, algo impensável para a época da edição da referida Instrução.

A letra $a$ do item II da Instrução define como condições artificiais de demanda, oferta ou preço de valores mobiliários

"aquelas criadas em decorrência de negociações pelas quais seus participantes ou intermediários, por ação ou omissão dolosa provocarem, direta ou indiretamente, alterações no fluxo de ordens de compra ou venda de valores mobiliários".

Para a configuração do ilícito deve haver, portanto, uma negociação, previamente combinada, da qual decorrerá uma alteração no fluxo de ordens de compra ou venda de um ou mais determinados valores mobiliários. Nessa negociação, não se verifica o natural conflito de interesses entre a oferta e a demanda que regula o mercado, representando uma vontade comum.

Assim, percebe-se que a proteção da norma se volta para o mercado e a livre formação de preços. A demanda, oferta ou preço de determinado valor mobiliário que foi alterada deixa de ser um reflexo do mercado.

No julgamento do Processo Administrativo Sancionador (PAS) n. ${ }^{\circ}$ 2/99 em 06/09/2001, o então Diretor Relator Luiz Antonio de Sampaio Campos votou:

"O prejuízo potencial dirige-se à generalidade dos detentores de determinado valor mobiliário e ao mercado como um todo, que receberiam uma sinalização fictícia a respeito de determinado valor mobiliário. Nesse mesmo tipo de operação, entendo que não há ganho ou perda entre as partes que participam da criação dessas condições artificiais, são operações que, na verdade, não existiriam em essência, não fosse a pretensão de se criar um falso mercado, um falso parâmetro de preço ou volume. Percebe-se, portanto, que deste tipo de infração resultariam prejuízos a um número considerável de investidores, e, por que não dizer, à estabilidade e integridade do mercado" 33

Ressalta-se que constitui um ilícito administrativo de mera conduta, não exigindo que o sujeito tenha como fim a obtenção de lucro. Nesse sentido é o voto da então Diretora Relatora Norma Parente no âmbito do PAS n. ${ }^{\circ}$ 16/2001, julgado em 03/11/2005:

${ }^{33}$ PAS n.. 2/99, Diretor Relator Luiz Antonio de Sampaio Campos, julgado em 06/09/2001. Disponível 
"não exige, para a sua configuração, a existência de prejuízo (...). Para tanto, basta que se verifiquem alterações no fluxo de ordens de compra ou venda dos papéis decorrentes de negociações preestabelecidas, tal como ocorreu no caso em tela, em que a bolsa foi indevidamente utilizada para satisfação de interesses particulares, a partir da livre transferência de recursos entre participantes do mesmo grupo em operações que não visavam efetivamente transferir a propriedade dos títulos negociados". ${ }^{34}$

Exemplo desse ilícito seria o esquema conhecido como "esquentaesfria" que consistiria em, por meio da realização de operações aparentemente lícitas no mercado de valores mobiliários, mas na verdade arranjadas, fabricar prejuízo para quem pretende "esfriar dinheiro", ou seja, apresentar perdas e gerar lucro para os que pretendem "esquentar dinheiro", ou seja, apresentar ganhos. As perdas, a serem contabilizadas, reduziriam eventual lucro tributável do perdedor, o que configuraria uma burla ao Fisco. Os lucros, por sua vez, justificariam o acréscimo patrimonial da pessoa física ou jurídica que o auferiu, conferindo uma origem lícita para recursos que tal pessoa já possuía, porém, sem origem lícita ou declarada ao Fisco. ${ }^{35}$

Já a manipulação de preços no mercado de valores mobiliários, presente na letra $b$ do item II da referida instrução, consiste na

"utilização de qualquer processo ou artifício destinado, direta ou indiretamente, a elevar, manter ou baixar a cotação de um valor mobiliário, induzindo terceiros à sua compra e venda".

À primeira vista, esse ilícito pode se confundir com a criação de condições artificiais. No entanto, verificam-se diferenças. A manipulação de preços se configura a partir de um processo ou artifício que altere a cotação de um valor mobiliário com o objetivo de induzir terceiros à compra ou venda.

Assim, a finalidade maior é a indução ao erro, com a criação de um falso mercado para determinado papel, de modo que terceiros acabem por adquirir o título manipulado a um preço que, por conseguinte, não refletirá o seu verdadeiro valor. ${ }^{36}$

\footnotetext{
${ }^{34}$ PAS n. ${ }^{\circ}$ 16/2001, Diretora Relatora Norma Parente, julgado em 03/11/2005. Disponível em <http://www.cvm.gov.br/export/sites/cvm/sancionadores/sancionador/anexos/2005/20051103 PA S 1601.pdf>. Acesso em 18/11/2018.

${ }^{35}$ PAS 02/2002, Diretor Relator Pedro Oliva Marcílio de Sousa, julgado em 17/01/2007.

${ }^{36}$ SANTOS, Alexandre Pinheiro dos; WELLISCH, Julya Sotto Mayor; BARROS, José Eduardo Guimarães. Op. cit., p. 118.
} 
No entanto, assim como a criação de condições artificiais, não exige a comprovação de qualquer resultado, constituindo ambos ilícitos administrativos formais ou de perigo abstrato.

Percebe-se também que a abrangência da criação de condições artificiais, que inclui a alteração da demanda, oferta ou preço, é maior do que a manipulação, que trata apenas da modificação artificial de preços. Assim,

"se duas instituições financeiras, desejando criar uma 'aparência' de liquidez para determinada ação, passam a negociá-la entre si, aumentando o volume de transações, sem que sua cotação seja alterada, caracteriza-se a criação de condições artificiais, mas não a manipulação de preços, na esfera do direito administrativo sancionador". 37

Um exemplo de manipulação de preços é o pump and dump, que será estudado posteriormente nesse trabalho. Esse mecanismo consiste em disseminar uma falsa informação tendo adquirido previamente grande quantidade de determinado papel, com o objetivo de aumentar o interesse dos investidores e, assim, elevar o seu preço, momento em que os papéis são alienados.

A letra $c$, por sua vez, do item II da ICVM 8/79 discorre sobre operação fraudulenta no mercado de valores mobiliários: é aquela em que se utilize ardil ou artifício destinado a induzir ou manter terceiros em erro, com a finalidade de se obter vantagem ilícita de natureza patrimonial para as partes na operação, para o intermediário ou para terceiros.

A sua redação é consideravelmente ampla, englobando qualquer mecanismo ardiloso com o fim de enganar e induzir terceiros a erro para obter vantagem patrimonial indevida, podendo ser adequando a inúmeras situações.

Nelson Eizirik defende que o conceito de operação fraudulenta é de exemplificação difícil, senão impossível, constitituindo atualmente, à semelhança do crime de estelionato, uma espécie de 'arma de reserva',

\footnotetext{
${ }^{37}$ EIZIRIK, Nelson et atl. Mercado de Capitais Regime Jurídico. $2^{\mathrm{a}}$ Ed, Rio de Janeiro: Renovar,
} 2008. p. 521-522. 
empregável apenas quando outras normas que reprimem diretamente determinada conduta não possam ser aplicadas. ${ }^{38}$

Assim como os outros ilícitos, a existência de prejuízo ao investidor não é requisito para a caracterização da operação fraudulenta. Não é necessário sequer que o agente tenha, de fato, obtido a vantagem indevida e, muito menos, causado prejuízo a terceiros. ${ }^{39}$

Segundo o então Diretor Relator Eli Loria no julgamento do PAS 20/2003, realizado em 01/07/2009, seria desnecessário saber se tal ou qual participante do mercado foi prejudicado. ${ }^{40}$

Dessa forma, o que deve ser demonstrado é a intenção de, por meio do comportamento fraudulento, induzir ou manter alguém em erro para obter a vantagem indevida.

A título de exemplo, pode ser configurado tal ilícito na falsificação de procuração com o fim de alienar ações que não são de titularidade do alienante.

Por fỉm, a instrução conceitua a prática não equitativa no mercado de valores mobiliários na letra $d$ do item II:

"aquela de que resulte, direta ou indiretamente, efetiva ou potencialmente, um tratamento para qualquer das partes, em negociações com valores mobiliários, que a coloque em uma indevida posição de desequilíbrio ou desigualdade em face dos demais participantes da operação".

Seguindo a linha dos demais ilícitos, a definição da prática não equitativa é, portanto, demasiadamente ampla, acolhendo qualquer situação provocada de forma dolosa que acarrete em uma posição de desequilíbrio para uma das partes em operações com valores mobiliários. Não se exige, para a sua caracterização, a ocorrência de prejuízo ou lucro.

Segundo a Nota Explicativa CVM n. ${ }^{\circ}$ 14/79, pretendeu-se com a amplitude das normas emprestar maior flexibilidade à atuação disciplinadora

\footnotetext{
${ }^{38}$ EIZIRIK, Nelson. Aspectos modernos do Direito Societário. Rio de Janeiro: Renovar. 1992. p. 188.

${ }^{39}$ SANTOS, Alexandre Pinheiro dos; WELLISCH, Julya Sotto Mayor; BARROS, José Eduardo Guimarães. Op. cit., p. 122.

40 PAS 20/2003, Diretor Relator Eli Loria, julgado em 01/07/2009. Disponível em 〈http://www.cvm.gov.br/sancionadores/sancionador/anexos/2009/20090701_PAS_2003.pdf>. Acesso em 18/11/2018.
} 
da CVM sobre o mercado, fazendo possível a paulatina adaptação das definições adotadas às necessidades demonstradas pela prática.

Destaca-se o voto do ex-diretor da CVM, Pedro Oliva Marcilio de Souza, no julgamento do PAS 28/2005:

"a jurisprudência da CVM tem exigido a presença dos seguintes elementos, para que a acusação por prática não equitativa se justifique: (i) negociação no âmbito do mercado de valores mobiliários; (ii) tratamento que coloque qualquer das partes da operação em uma indevida posição de desequilíbrio ou desigualdade em face dos demais; (iii) dolo específico de auferir proveito da situação; e (iv) ocorrência de resultado, que pode ser direto ou indireto, consistente no desequilíbrio para uma das partes”41

Cumpre ressaltar que os ilícitos previstos na ICVM 8/79 são diferentes formas de manipular o mercado. Nas palavras de Eizirik:

"o legislador tentou conjugar, num mesmo tipo penal, três figuras tidas como ilícitos administrativos: a criação de condições artificiais de demanda, oferta ou preço de valores mobiliários; a operação fraudulenta; e a manipulação de preços, disciplinadas pela Instrução CVM 08/1979”42

Em relação às práticas não equitativas, vale enfatizar que o mercado de valores mobiliários se rege por regras muito específicas, tendo em vista preservar, dentre outros, o princípio da equidade nas negociações, buscandose evitar que os agentes participantes do mercado possam se valer de privilégios - efetivos ou por eles próprios criados - devendo negociar, portanto, em igualdade de condições. ${ }^{43}$

A não igualdade em meio às negociações, portanto, quebra a confiança no regular funcionamento do mercado, ao passo em que a formação de preços deixa de ser fruto da atuação da oferta e demanda efetivamente existentes no mercado.

\footnotetext{
${ }^{41}$ PAS n.. 28/2005, Diretor Relator Pedro Oliva Marcilio de Souza, julgado em 03/07/2007. Disponível em <http://www.cvm.gov.br/export/sites/cvm/sancionadores/sancionador/anexos/2007/20070703_PA S_2805.pdf>. Acesso em 18/11/2018.

${ }^{42}$ EIZIRIK, Nelson (1992). Op. cit., p. 67.

${ }^{43}$ PAS n. ${ }^{\circ}$ SP2002/0564, Diretor Relator Wladimir Castelo Branco Castro, julgado em 19/11/2003.
} 


\subsection{Interface entre as esferas penal e administrativa}

É de fácil constatação, portanto, a previsão de condutas muito semelhantes nas esferas penal e administrativa. Nada impede, assim, que o mesmo ato seja ilícito nos termos da ICVM 8/79 e do artigo 27-C da lei 6.385/76 e, consequentemente, passível de condenação em ambas as instâncias.

O princípio do non bis in idem impede que o mesmo fato enseje mais de um julgamento ou condenação. Se, à primeira vista, essa máxima parece confrontar com o fenômeno aqui analisado, o seu alcance encontra limitações. A incidência de múltiplas normas punitivas a condutas praticadas no âmbito do mercado de capitais pode sujeitar em sanções aplicadas cumulativamente.

A dupla punição se explica pela autonomia das esferas penal, civil e administrativa, tese já consagrada nos tribunais superiores. As instâncias são independentes entre si e há uma clara distinção legal entre os órgãos competentes para julgar e aplicar sanções diversas em cada uma das esferas. A independência e autonomia das instâncias, portanto, é decorrência do próprio princípio da separação dos poderes. ${ }^{44}$

Para que houvesse um único poder sancionador do Estado, seria necessário submeter a manifestação estatal a um idêntico regime jurídico. No entanto, os princípios constitucionais, ao incidirem em relações penais ou de Direito Administrativo, revelam-se distintos, ainda que nominalmente idênticos. Há, portanto, uma diversidade substancial dos regimes jurídicos dos diversos poderes punitivos do Estado, não podendo ser configurado um unitário ius puniendi estatal. ${ }^{45}$

Como regra, os indícios de ilícitos no mercado de capitais são detectados pela CVM ou comunicados à autarquia por investidores e participantes do mercado. Assim, será instaurado inquérito administrativo

\footnotetext{
${ }^{44}$ Nesse sentido: Mandados de Segurança $\mathrm{n}^{0} 7.035$ e 7.863, ambos do STJ.

${ }^{45}$ OSÓRIO, Fábio Medina, Direito Administrativo Sancionador, $4^{\mathrm{a}}$ ed. São Paulo: Editora Revista dos Tribunais, 2011. p. 126-127.
} 
para investigar a fundo os fatos ou, diante de indícios suficientes para a caracterização do ilícito, será formulado diretamente termo de acusação. A autarquia, por sua vez, tem a responsabilidade de denunciar ao Ministério Público a ocorrência de indícios de ilícito penal na apuração de irregularidades no mercado. ${ }^{46}$ No entanto, o comportamento de cada órgão a partir do conhecimento dos fatos é absolutamente autônomo em relação ao outro - o Ministério Público não depende do término do processo administrativo ou mesmo qualquer ato por parte da autarquia para iniciar inquérito próprio ou mesmo oferecer denúncia.

Assim, a ação penal e o processo administrativo sancionador poderão tramitar simultaneamente, independentes entre si. Entretanto, essa independência não é absoluta, podendo a sentença penal gerar efeitos nas esferas cível e administrativa.

Pode ser verificada, portanto, uma vinculação entre as decisões das diferentes autoridades. O juiz penal possui certa prevalência sobre os demais, uma vez que a gravidade da sanção exige que a instrução criminal seja mais densa e complexa. A sentença penal absolutória transitada em julgado produzirá efeitos nas esferas administrativa e civil, na hipótese de reconhecimento da inexistência material do fato ou negativa da autoria.

No mesmo sentido já se posicionou o STF: "são independentes as instâncias penal e administrativa, só repercutindo aquela nesta quando se manifesta pela inexistência material do fato ou pela negativa de autoria". ${ }^{47}$

Nesse sentido, Norma Parente ensina que, se no âmbito do processo penal se conseguiu comprovar a negação de autoria ou até mesmo a inexistência do fato delituoso, não cabe a outras esferas judicantes contrariar tal conclusão. Isso ocorre na medida em que a falta de comprovação da não autoria ou da existência de fato delituoso no âmbito do processo penal passam a ser inquestionáveis também nas esferas civil e administrativa. O mesmo

\footnotetext{
${ }^{46}$ COMISSÃO DE VALORES MOBILIÁRIOS. Op. cit., p. 62.

${ }^{47}$ Mandado de Segurança n ${ }^{\circ}$ 22.438, Relator Ministro Moreira Alves, julgado em 20/11/97.
} 
não ocorre se a absolvição se deu não pela negativa de autoria, porém por insuficiência de provas de autoria. ${ }^{48}$

Em relação à sentença penal condenatória, o seu trânsito em julgado produzirá efeitos na esfera cível, na qual pode o ofendido executar a sentença penal a fim de obter a reparação de danos, segundo o artigo 63 do Código de Processo Penal. Por outro lado, a extensão dos efeitos não se aplica no âmbito administrativo, diante de ausência de expressa previsão e clara violação ao princípio do contraditório e ampla defesa.

A decisão administrativa, por sua vez, não tem qualquer efeito sobre a esfera penal, tendo o juiz autonomia para apreciar a questão, independentemente de qualquer decisão prolatada sobre o mesmo ilícito.

Ainda, cumpre ressaltar que a independência entre as esferas não deve impedir a comunicabilidade. Pelo contrário, as instâncias devem interagir e manter um relacionamento institucional, colaborando entre si. Nesse sentido, a CVM e o Ministério Público Federal firmaram entre si o Termo de Cooperação Técnica, cujo objetivo central é maximizar a efetividade nas ações conjuntas de prevenção, apuração e combate a práticas lesivas ao mercado de capitais. ${ }^{49}$

Por fim, devem ser feitas considerações sobre a aptidão do direito penal e as consequências do seu uso em determinadas áreas. Questiona-se a eficiência da atuação da esfera penal no âmbito do mercado de capitais. Seria o direito penal o instrumento mais adequado para a repressão dos ilícitos no mercado de capitais? A intervenção da esfera administrativa não seria suficiente para proteger os bens jurídicos tutelados? Como afirmou Peter Johnstone, "continua, no entanto, o debate de saber se é mais eficaz uma sanção penal ou não penal em geral para os crimes de colarinho branco" ${ }^{50}$

De acordo com Fábio Medina Osório, a sanção administrativa tem efeitos aflitivos, com alcance geral e potencialmente pro futuro, como

\footnotetext{
${ }^{48}$ PARENTE, Norma (2018). Op. cit., p. 833.

49 CVM e MPF prorrogam Termo de Cooperação Técnica. Disponível em <http://www.cvm.gov.br/noticias/arquivos/2018/20180508-2.html >. Acesso em 18/11/2018.

${ }^{50}$ JOHNSTONE, Peter. New Regulatory Architecture, in: European Financial Services Law, 1999. p. 202.
} 
consequência de uma conduta ilegal, tipificada em norma proibitiva, com uma finalidade repressora e disciplinar. Ambas as finalidades são compatíveis entre si, sendo o exercício do poder disciplinar, necessariamente, em alguma medida, também punitivo, embora busque um acentuado objetivo pedagógico. $^{51}$

Já o Direito Penal teria uma finalidade ressocializante e de reeducação, embora também deva desempenhar um papel de defesa social, segregando pessoas incapazes de conter seus impulsos ou vontades destrutivas da ordem normativa que cobre o tecido social.

No entanto, não é isso que se verifica na prática, sendo ineficaz para atingir a finalidade ressocializante que preconizava. Assim, o Direito Penal vem adquirindo um caráter funcionalista e puramente punitivo na proteção dos bens jurídicos, utilizando-se, em larga escala, da aplicação de pena privativa de liberdade.

É inegável que o órgão regulador do mercado de capitais possui ampla experiência e alta especialização técnica em relação ao tema.

Daniel Entrena Ruiz reconhece a maior efetividade do direito administrativo sancionador, não apenas por favorecer uma prevenção em maior grau que o direito penal, mas por ser mais eficaz contra as condutas lesivas ao mercado de capitais. O autor afirma que a utilização do direito administrativo sancionador estaria em consonância com o princípio da intervenção mínima, propondo a derrogação do tipo penal ou, ao menos, a sua aplicação única e exclusivamente para os casos mais graves. ${ }^{52}$

Em contraponto, Montoy Antón defende que ainda que o direito administrativo sancionador seja suficiente para representar proteção às condutas ilícitas que afetam o bem jurídico, não deve representar óbice à atuação do direito penal com a mesma finalidade. As agressões ao bem jurídico seriam revestidas de gravidades distintas e, portanto, devem as condutas ser sancionadas com maior ou menor gravidade por um tipo de

\footnotetext{
${ }^{51}$ OSÓRIO, Fábio Medina. Op. cit., p. 100.

${ }^{52}$ RUIZ, Daniel Entrena. El empleo de información privilegiada em el mercado de valores: un estudio de su régimen administrativo sancionador. Navarra: Editorial Arazandi, 2006. p. 405.
} 
direito ou outro. As ações de maior periculosidade, então, deveriam ser discutidas no âmbito do direito penal. ${ }^{53}$

Por fim, Otávio Yazbek, num caminho inverso, defende a autoregulação do mercado, que, importante ressaltar, difere-se de uma falta de regulação:

"cumpre reconhecer que ela é, de fato, regulação da atividade econômica, sendo objeto de uma imposição e não fruto de 'forças equilibradoras' do mercado. Tratase, assim, de uma regulação 'artificial', imposta, ainda que o seja pela própria coletividade dos agentes regulados. Evidencia-se, com isso, o segundo aspecto da autorregulação, o fato de ela resultar de uma organização coletiva que impõe uma ordem, um conjunto de regras ou procedimentos a seus membros - ela não nasce do conjunto de operações, mas de uma estrutura que se destaca daquelas operações e dos agentes que as realizam e que, sobre eles, deverá atuar. Por fim, do até aqui exposto ressalta também, o caráter extra-estatal da auto-regulação, que é desenvolvida por órgãos coletivos privados". ${ }^{4}$

${ }^{53}$ ANTÓN, Antonio J. Monroy. El delito de abuso de información privilegiada em el mercado de valores. Madrid Dijusa, 2006. p. 133.

${ }^{54}$ YAZKEK, Otávio. Op. cit., p. 208-209. 


\section{Capítulo 3 - Manipulação de mercado em espécie}

O desenvolvimento tecnológico levou a inúmeras inovações nas negociações do mercado de capitais. O uso de robôs tem sido muito expressivo, sobretudo nos EUA. Os chamados robô traders são capazes de disparar milhares de ordens de compra e venda por segundo.

Ao passo em que o uso de robôs nas negociações não é proibido, diferentes práticas para manipular o mercado através da sua utilização já foram elaboradas.

\subsection{Spoofing}

$O$ spoofing é uma prática para criar liquidez artificial com ofertas de tamanho fora do padrão do livro de ofertas, com o objetivo único de atrair os investidores a superar a oferta inicial e gerar negócios do lado oposto do livro. Após o alcance de determinado preço, as ordens originais são imediatamente canceladas. $^{55}$

O que o manipulador busca é atrair contrapartes para a compra ou venda pretendida. Ele usa uma das propostas - de compra ou de venda apenas para maquiar a operação. Ao mesmo tempo em que dá uma ordem de venda, por meio de algoritmos, lança uma ordem expressiva de compra da mesma ação, criando, de forma artificial, uma alta demanda.

Isso leva os participantes do mercado a acreditarem na valorização ou queda desse ativo, melhorando suas ofertas, o que leva o operador a atingir o preço pretendido. Com a execução da venda ou compra, a oferta do lote expressivo é cancelada.

O spoofing ocorre em diferentes etapas. A manobra se inicia com a inserção da oferta. O próximo passo é a criação de falsa liquidez no lado

\footnotetext{
${ }^{55}$ PIMENTA, Guilherme. Spoofing: nova forma de manipular o mercado de ações. Disponível em $<$ https://www.jota.info/justica/spoofing-nova-forma-de-manipular-o-mercado-de-acoes03092017>. Acesso em 18/11/2018.
} 
oposto, que é feito com a inserção de oferta do lado oposto ao que verdadeiramente deseja negociar. Essa quantidade de oferta é de tamanho fora do padrão do livro e é isso que atrai os investidores. O tamanho da oferta gera pressão de liquidez, considerada verdadeira pelos demais participantes do mercado. ${ }^{56}$

Em seguida, a reação dos investidores à falsa liquidez altera o preço. Ao atingir o preço desejado e fechar o negócio, o manipulador cancela a oferta artificial, o que ocorre em questão de segundos.

Pode-se atingir a falsa liquidez a partir de uma só oferta ou um conjunto. Além disso, a execução de uma pequena parte das ofertas não descaracteriza o spoofing.

Atenta-se para o fato de que o mero cancelamento de ofertas, a inserção de ofertas de tamanho superior ao lote padrão e a verificação de ofertas dos dois lados do livro não configuram spoofing.

Em 2018, a CVM julgou o primeiro caso de spoofing envolvendo a Paiffer Management, caso que será melhor analisado no Capítulo 4. O Colegiado entendeu que a prática se enquadra no ilícito da manipulação de preços do item II, letra “b” da Instrução CVM nº 8/1979.

\subsection{Layering}

O layering, por sua vez, é a prática de inserção de ofertas em camadas no livro de ofertas - por isso o seu nome - com o objetivo de levar outros investidores a inserir ou modificar ofertas, propiciando a realização de negócios no lado oposto.

Assim como o spoofing, cria-se uma liquidez artificial, mas em um processo distinto. O manipulador realiza, em poucos segundos, uma camada ofertas de lotes menores em níveis sucessivos de preços, ascendentes ou descendentes, com o fim de induzir os investidores a fazerem melhores

\footnotetext{
${ }^{56}$ TORRES, Marcos José Rodrigues; CUTER, Julio Cesar; CALABRÓ, Luiz Felipe Amaral. Monitoração de ofertas - Spoofing e Layering. Disponível em http://www.bsmautorregulacao.com.br/assets/file/noticias/Monitoraca_Ofertas.pdf>. Acesso em 18/11/2018.
} 
ofertas. Com a obtenção do preço pretendido, as ofertas artificiais são canceladas.

Na prática, o resultado do layering e do spoofing é o mesmo, tendo como fim a atração de investidores para viabilizar a execução das ofertas em patamares de preços desejados. ${ }^{57}$

O European Securities and Markets Authority (ESMA) apontou spoofing e layering, no Guideline 5 dos Guidelines on systems and controls in an automated trading environment for trading platforms, investment firms and competent authorities, como casos de manipulação de mercado de grande interesse e preocupação em um ambiente de negociação automatizado, os definindo como

"submitting multiple orders often away from the touch on one side of the order book with the intention of executing a trade on the other side of the order book. Once that trade has taken place, the manipulative orders will be removed". ${ }^{58}$

No Reino Unido, o Financial Conduct Authority (FCA) multou o negociador de alta frequência Michael Coscia em 903,176 dólares pela prática de layering, na qual utilizou um algoritmo desenvolvido por ele próprio, obtendo um lucro indevido de 279,920 dólares. ${ }^{59}$

\footnotetext{
${ }^{57}$ PARENTE, Norma (2018). Op. cit., p. 684.

${ }^{58}$ Guidelines on systems and controls in an automated trading environment for trading platforms, investment firms and competent authorities. Disponível em $<$ https://www.esma.europa.eu/sites/default/files/library/2015/11/2011-456 0.pdf $>$. Acesso em $18 / 11 / 2018$.

$59 \quad$ FCA fines US based oil trader US $\$ 903 \mathrm{~K}$ for Market manipulation $<$ https://www.fca.org.uk/news/press-releases/fca-fines-us-based-oil-trader-us-903k-marketmanipulation>. Acesso em 18/11/2018.
} 


\section{Capítulo 4 - Análise de casos}

\subsection{Mundial S.A.}

A ação penal n. ${ }^{\circ}$ 506709618.2012.4.04.7100/RS resultou na primeira condenação penal do Ministério Público Federal com atuação da Comissão de Valores Mobiliários como assistente de acusação, pelo delito de manipulação de mercado, previsto no art. 27-C da Lei $n^{\circ} 6.385 / 76 .{ }^{60} \mathrm{~A}$ sentença data de 11/11/2016. O caso ficou conhecido como "bolha do alicate", por se tratar da fabricante gaúcha de tesouras e alicates de unha Mundial. ${ }^{61}$

O caso movimentou o mercado entre 2010 e 2011, quando a ação da empresa passou a ser fortemente negociada, chegando a superar em alguns dias o volume de grandes companhias. Em apenas cinco meses, entre março de 2011 para julho do mesmo ano, as ações se valorizaram de $\mathrm{R}$ 0,23 para $\mathrm{R} \$ 7,01$, um aumento impressionante de $2.950 \%$.

No fim de julho, no entanto, as ações despencaram, voltando a valer somente alguns centavos, afetando muitos investidores que, em meio a um cenário tão atraente, adquiriram ações da companhia, pouco conhecida, sem liquidez e sem muita cobertura de analistas.

A empresa, desde o fim de 2010, investia em divulgação e marketing para valorizar seus papéis, com intenção de entrar no Novo Mercado, melhorias operacionais, parcerias com fundos internacionais.

No entanto, não foi isso que gerou a bolha especulativa. Foi identificado um grupo de investidores conduzidos por Rafael Ferri, agente autônomo de investimentos, que teria realizado conjunto de operações que

\footnotetext{
${ }^{60}$ CVM e MPF obtêm primeira condenação penal por manipulação de mercado do Brasil. Disponível em < http://www.cvm.gov.br/noticias/arquivos/2016/20161111-2.html>. Acesso em 18/11/2018.

61 CVM condena Rafael Ferri por manipulação de ações da Mundial. Disponível em $<$ https://exame.abril.com.br/mercados/cvm-condena-rafael-ferri-por-manipulacao-de-acoes-damundial/>. Acesso em 18/11/2018.
} 
caracterizavam manipulação de mercado. Ferri teria, então, articulado um esquema que inflou as ações da Mundial S.A.

Ele teria formado um grupo de investidores que aportaram significativo volume de recursos na aquisição de ações de emissão da Mundial entre maio de 2010 e julho de 2011.

Ele manteria ligações estreitas com Michael Ceitlin, então Diretor Presidente e de Relações com Investidores da Mundial. Rafael Ferri teria utilizado informações estratégicas advindas da relação com Ceitlin. Esse repassava a Ferri informações relativas a fatos relevantes antes da divulgação ao mercado, violando o dever legal de sigilo previsto na Instrução CVM 358 e na Lei 6.404/76.

Ferri era acionista da companhia e negociava volumes elevadíssimos das ações da Mundial, para dar volume e valorizar o papel. Além disso, exercia ingerência e controle sobre seus clientes, induzindo-os a adquirir as ações de emissão da Mundial, bem como tentando impedir a venda para não influenciar negativamente a cotação.

O agente adquiriu cerca de 140 milhões de ações preferenciais da Mundial, 102\% do total de ações dessa espécie negociadas entre março de 2010 e julho de 2011.

Verificou-se que as altas na cotação das ações eram acompanhadas de grande volume de negociações realizadas por Rafael Ferri, e, na maioria das vezes, em lotes mínimos, o que resultava em condições anormais de liquidez.

A $7^{\text {a }}$ Vara Federal de Porto Alegre condenou os réus Rafael Ferri e Michael Ceitlin, pelos crimes de manipulação de mercado e insider trading, à pena privativa de liberdade estabelecida em 3 anos e 9 meses de reclusão, a ser cumprida em regime inicial aberto, com pagamento de multas fixadas em $\mathrm{R} \$ 2.328 .382,00$, corrigidos monetariamente a partir de 26/7/2011 para Ferri.

Ambas as penas restritivas de liberdade foram substituídas por prestação de serviços à comunidade ou a entidades públicas e por prestação pecuniária fixa em 50 salários mínimos vigentes na data do efetivo 
pagamento, para cada réu, a serem recolhidos em favor de instituições de cunho social, determinadas em execução.

A primeira sentença judicial em relação a manipulação de mercado representa um marco na atuação do Estado, em conjunto com a CVM e a Polícia Federal, na defesa da integridade do mercado de capitais, em um trabalho de cooperação de prevenção e repressão de ilícitos no mercado financeiro, promovendo uma maior confiança por parte dos investidores.

Em 8/12/2016, a CVM julgou o Processo Administrativo Sancionador $\mathrm{CVM} \mathrm{n}^{\mathrm{o}} \mathrm{RJ} 2012 / 11002$, referente ao mesmo caso. O processo foi instaurado pela Superintendência de Relações com o Mercado e Intermediários (SMI) por indícios de manipulação do preço das ações de emissão da Mundial S.A., de acordo com o inciso II, letra " $b$ ", da Instrução CVM $8 .{ }^{62}$

Ferri também foi acusado de uso de informação privilegiada, em infração ao disposto no art. $155, \S 4^{\circ}$ da Lei 6.404/76, combinado com o art, $13, \S 1^{\circ}$, da Instrução CVM 358. Já Ceitlin, por violação do dever de guardar sigilo sobre informação relevante não divulgada, em infração ao disposto no art. $155, \S 1^{\circ}$, da Lei 6.404/76.

Haviam diversos acusados no processo, mas o Colegiado da CVM decidiu por condenar somente Rafael Ferri pela manipulação de mercado. O Diretor Relator Roberto Tadeu entendeu pela inexistência de provas a caracterizar a ocorrência do ilícito de manipulação de preço em relação aos outros acusados e demais acusações.

Foi definida pena de proibição temporária, pelo prazo de 5 anos, de praticar atividade de agente autônomo de investimento e de atuar em uma ou mais modalidades de operação no mercado de valores mobiliários.

\footnotetext{
62 CVM condena por manipulação de preço. Disponível em <http://www.cvm.gov.br/noticias/arquivos/2016/20161208-2.html>. Acesso em 18/11/2018.
} 


\subsection{Companhia de Saneamento do Paraná S.A. (Sanepar)}

Em 18/12/2015, a CVM julgou o Processo Administrativo Sancionador $\mathrm{n}^{\mathbf{o}}$ RJ2012/9808, instaurado pela SMI para investigar a negociação de ações de emissão da Companhia de Saneamento do Paraná S.A. (Sanepar). ${ }^{63}$ Foi verificada repentina valorização pouco antes da divulgação de Fato Relevante.

No dia 21/12/11, o Conselho de Administração da Companhia aprovou o Planejamento Estratégico de 2012-2014, que previa o reajuste de 16\% das tarifas de saneamento básico da Sanepar, a vigorar a partir de março de 2012.

No mesmo dia, a Sanepar divulgou Fato Relevante sobre a aprovação do Planejamento Estratégico, sem mencionar a perspectiva de reajuste de tarifas. Em 16.02.12, a Companhia divulgou Fato Relevante informando que reajustaria os valores de suas tarifas de saneamento básico em 16,5\%.

Verificou-se que o preço das cotações das ações preferenciais da Sanepar aumentou 32,15\% no período compreendido entre a aprovação do Planejamento Estratégico pelo Conselho de Administração da Sanepar e o dia anterior à divulgação do Fato Relevante referente ao reajuste das tarifas.

A Vinci Equities Gestora de Recursos Ltda. teria vendido ações preferenciais da Sanepar em nome de seus clientes no período compreendido entre 27.12.11 e 16.02.12. Segundo a Acusação, pequenos lotes de ações eram vendidos toda vez que o preço do ativo atingia determinado valor, com o intuito de manter a cotação das ações da Sanepar controlada dentro de um intervalo de preço pré-determinado por ela, o que teria permitido a gestora adquirir as ações por um preço inferior.

Portanto, as operações de venda não tiveram por finalidade a obtenção de lucros, mas o controle do preço dessa ação nos patamares desejáveis pela

\footnotetext{
${ }^{63}$ PAS RJ2012/9808, Diretor Relator Roberto Tadeu Antunes Fernandes, julgado em 18/12/2015. Disponível 
Vinci Equities. A manipulação se dava quando o preço subia repentinamente e saía do intervalo, ao passo que a Vinci realizava as vendas para deslocar o preço do ativo para um valor menor.

O Colegiado entendeu que a sistemática de compras e vendas realizada pela gestora se encaixa na tipificação de manipulação de preços definida na Instrução CVM 08, uma vez que utilizou-se de artifícios, no caso, a venda de ações por preços inferiores aos praticados pelo mercado, com a intenção de alterar a cotação da ação, forçando-a para baixo, e induzindo terceiros à compra das ações.

O Colegiado decidiu pela condenação da Vinci Equities Gestora de Recursos Ltda. à pena de multa no valor de $\mathrm{R} \$ 500.000,00$, por prática de manipulação de preços das ações preferenciais da Sanepar.

A Acusação também imputou à Vinci o uso de informação privilegiada, juntamente a outros acusados. No entanto, o Colegiado não considerou suficientes os indícios apontados, absolvendo todos os acusados em relação a essa infração.

No caso específico da Vinci Equities, foi apontado que a data em que foi aprovado o Planejamento Estratégico 2012-2014 da Sanepar coincidiria com o início das negociações dos fundos por ela geridos. A gestora declarou que a compra das ações se deu por uma análise fundamentalista da Companhia por parte de sua equipe, identificando um elevado potencial de crescimento no setor de saneamento, alinhado a uma demanda com alta previsibilidade.

\subsection{Paiffer Management Ltda.}

O Colegiado da CVM julgou, em 13/03/2018, o Processo Administrativo Sancionador $\mathrm{n}^{\mathbf{0}}$ RJ2016/7192, instaurado pela SMI para apurar a prática de manipulação de preços por meio da inserção de ordens artificiais de compra e venda, na modalidade spoofing, em infração ao inciso I c/c item II, "b", da Instrução CVM 8, que teria sido realizada pela Paiffer 
Management e seu sócio, José Joaquim Paifer. Foi o primeiro processo no país envolvendo esse novo tipo de manipulação, já abordado anteriormente nesse trabalho.

A estratégia de spoofing teve como característica a inserção de ofertas de compra ou de venda com lote expressivo de ações e opções no segmento Bovespa e contratos futuros no segmento BM\&F. No entanto, em curto intervalo de tempo, foram canceladas, com o objetivo de atrair contrapartes para a execução de suas ofertas, constantes no lado oposto do livro, por meio de simulação de pressão compradora ou vendedora nos valores mobiliários. 64

O diretor Henrique Machado afirmou em seu voto:

“(...) verifica-se a conduta dolosa e pré-ordenada de registrar ofertas de compra ou venda sem a intenção de executá-las, mas, sim, de promover a realização de negócio em cotação de preço artificial induzindo terceiros à sua compra ou venda." $" 65$

O padrão de operação foi repetido milhares de vezes com 97,27\% de taxa de cancelamento integral da oferta expressiva após intervalo médio de permanência de quatro segundos no livro de ofertas dos contratos.

Naturalmente, a conduta isolada de ofertar em ambos os lados do livro, no de ofertas de venda e no de ofertas de compra, não é irregular, assim como o registro de ofertas expressivas em qualquer desses lados e o rápido cancelamento de qualquer um desses registros.

No entanto, a organização proposital desses elementos em um mecanismo destinado a alterar o preço de um valor mobiliário induz o investidor à compra ou venda. Assim, verifica-se a manipulação de preços na modalidade spoofing.

A existência de uma oferta de magnitude suficiente a alterar a cotação de um valor mobiliário e, do outro, uma oferta do mesmo participante que

64 PAMPLONA, Nicola. CVM multa acusados de nova forma de manipulação do mercado. Disponível em <https://www1.folha.uol.com.br/mercado/2018/03/cvm-multa-acusados-de-novaforma-de-manipulacao-do-mercado.shtml>. Acesso em 18/11/2018.

65 PAS RJ2016/7192, Diretor Relator, julgado em 13/03/2018. Disponível em <http://www.cvm.gov.br/export/sites/cvm/sancionadores/sancionador/anexos/2018/RJ20167192_J ose_Paifer.pdf $>$. Acesso em 18/11/2018. 
tem vantagem pela variação de preço, alinhada com o curtíssimo intervalo de permanência da oferta expressiva, com repetido cancelamento dessa mesma oferta e pelo padrão reiterado de operação, evidenciam a estratégia do agente. A intenção não é concretizar a oferta expressiva, mas apenas induzir terceiros a adquirir seus ativos do outro lado do livro de ofertas.

O Colegiado, então, condenou ambos os acusados, sendos aplicadas multas a José Joaquim Paifer, no valor de $\mathrm{R} \$$ 684.000,00, e a Paiffer Management Ltda., no valor de R \$ 1.710.000,00, o equivalente a duas vezes a vantagem econômica obtida por cada um pela prática de manipulação de preços. 


\section{Capítulo 5 - Manipulação de mercado no direito comparado}

\subsection{EUA}

No direito norte-americano, a agência responsável pelo funcionamento do mercado de capitais é a Securities and Exchange Commission (SEC). Criada em 1934 pelo Congresso americano, pouco tempo depois da Grande Depressão de 1929, marcado pela quebra da Bolsa de Valores de Nova York, o que gerou uma perda de confiança dos investidores no mercado de valores mobiliários norte-americano. ${ }^{66}$

Dentre outras funções, ela atua diretamente na manutenção do regular funcionamento do mercado de valores mobiliários e na proteção dos investidores contra práticas fraudulentas dentro do mercado de capitais.

A SEC não possui autoridade na esfera penal, tendo o papel de encaminhar qualquer irregularidade constatada para o Ministério Público, mas pode aplicar penalidades monetárias e uma série de proibições, semelhante à atuação da Comissão de Valores Mobiliários.

Os Estados Unidos possuem uma série de leis federais que regem o mercado de capitais. A primeira foi o Securities Act de 1933, que padronizou a legislação relativa ao mercado financeiro em todo o país e instituiu o dever de divulgar informações relevantes aos investidores e a transparência, a fim de evitar fraudes. Possuía uma nítida preocupação em proteger o investidor, prevendo, em sua seção 17(a), punição para qualquer pessoa que, mediante uso de qualquer meio de comunicação no comércio interestadual ou correio, publique ou circule notícia, anúncio ou qualquer outra forma de comunicação de conteúdo falso, pelo efeito que possa produzir aos investidores.

\footnotetext{
${ }^{66}$ REIS, Tiago. SEC: Saiba O Que Faz Essa Agência Dentro Do Mercado De Valores Dos EUA. Disponível em <https://www.sunoresearch.com.br/artigos/sec/ >. Acesso em 18/11/2018.
} 
Em 1934, foi editado o Securities Exchange Act, que, além de ser responsável pela criação da SEC, deu uma melhor formatação ao Securities Act, dispondo expressamente sobre possibilidade de punição contra atos de manipulação ou fraude em negociações com valores mobiliários.

Em sua seção 9, tratou sobre a manipulação de mercado:

"It shall be unlawful for any person, directly or indirectly, by the use of the mails or any means or instrumentality of interstate commerce, or of any facility of any national securities exchange, or for any member of a national securities exchange-

(1) For the purpose of creating a false or misleading appearance of active trading in any security other than a government security, or a false or misleading appearance with respect to the market for any such security, (A) to effect any transaction in such security which involves no change in the beneficial ownership thereof, or $(B)$ to enter an order or orders for the purchase of such security with the knowledge that an order or orders of substantially the same size, at substantially the same time, and at substantially the same price, for the sale of any such security, has been or will be entered by or for the same or different parties, or $(C)$ to enter any order or orders for the sale of any such security with the knowledge that an order or orders of substantially the same size, at substantially the same time, and at substantially the same price, for the purchase of such security, has been or will be entered by or for the same or different parties.

(2) To effect, alone or with 1 or more other persons, a series of transactions in any security registered on a national securities exchange, any security not so registered, or in connection with any security-based swap or security-based swap agreement with respect to such security creating actual or apparent active trading in such security, or raising or depressing the price of such security, for the purpose of inducing the purchase or sale of such security by others."

Essa seção define como passível de punição a realização de transações que levem o investidor a acreditar que determinado valor mobiliário tenha o preço estabilizado no mercado, criando uma falsa aparência de liquidez, ou que engane o investidor quanto ao real valor do ativo, tendo o preço sido artificialmente alterado para cima ou para baixo. O investidor lesado tem direito de processar o manipulador, mas tem o ônus de provar que o preço foi efetivamente influenciado pela manipulação e, ainda, demonstrar o dolo do agente. Seria necessário, portanto, analisar o aspecto subjetivo do tipo penal, ou seja, a vontade de induzir o investidor a erro em relação àqueles valores mobiliários. ${ }^{67}$

67 CORNELL LAW SCHOOL. Securities Exchange Act of 1934. Disponível em $<$ https://www.law.cornell.edu/wex/securities exchange act_of 1934>. Acesso em 18/11/2018. 
Além disso, outro dispositivo utilizado é a Rule 10(b)-5. Esse é o principal instrumento da SEC para reprimir a manipulação de mercado e teve um papel importante em abranger as fraudes por parte dos investidores. A razão é que, por ser muito mais comum que a fraude fosse identificada na venda de valores mobiliários, até 1942, não era legalmente proibida a fraude por parte dos compradores.

Assim, a SEC editou a referida rule para que tais condutas não fossem incentivadas no mercado financeiro. $\mathrm{O}$ dispositivo se estende para proibir qualquer conduta com o poder de manipular ou enganar durante a negociação de um valor mobiliário, além da utilização de qualquer meio ou artifício para cometer uma fraude. ${ }^{68}$

"Rule 10b-5: Employment of Manipulative and Deceptive Practices":

It shall be unlawful for any person, directly or indirectly, by the use of any means or instrumentality of interstate commerce, or of the mails or of any facility of any national securities exchange,

(a) To employ any device, scheme, or artifice to defraud,

(b) To make any untrue statement of a material fact or to omit to state a material fact necessary in order to make the statements made, in the light of the circumstances under which they were made, not misleading, or

(c) To engage in any act, practice, or course of business which operates or would operate as a fraud or deceit upon any person,

in connection with the purchase or sale of any security."

Apesar de não estar previsto, as Cortes americanas admitem que particulares que adquiriram ou venderam valores mobiliários induzidos por condutas manipulativas utilizem-se desse dispositivo para processar o manipulador.

As penas cominadas pelo descumprimento das regras da Securities and Exchange Act são estabelecidas em sua seção 32, e preveem o limite máximo para penas de multa em vinte e cinco e cinco milhões de dólares, respectivamente, para pessoas jurídicas e pessoas físicas. ${ }^{69}$ No tocando à

\footnotetext{
${ }^{68}$ US SECURITIES AND EXCHANGE COMISSION. The Laws That Govern the Securities Industry. Disponível em <https://www.sec.gov/answers/about-lawsshtml.html\#secexact1934>. Acesso em 18/11/2018.

${ }^{69}$ THEL, Steve. Taking Section 10(b) Seriously: Criminal Enforcement of SEC Rules Disponível em
} 
pena privativa de liberdade, tem como estabelecida pena máxima de 20 anos de prisão, consideravelmente superior à pena brasileira de oito anos para o ilícito de manipulação de mercado.

\subsection{União Europeia}

\subsubsection{Regulamento (UE) n. 596/2014}

A tutela penal do Mercado de Capitais tem origem no Código Penal Francês de 1810, que já tratava da manipulação de mercado como uma das formas do crime de manipulação de preços. Teve forte influência sobre os demais sistemas legais europeus no século XIX. ${ }^{70}$

Num sentido comunitário, o primeiro marco de combate aos ilícitos no mercado de capitais foi a edição, em 13 de novembro de 1989, da Diretiva 89/592/CEE, que garantia transparência informativa e a leal utilização da informação, reprimindo o uso indevido de informação privilegiada.

Em 28 de janeiro de 2003, foi editada a Diretiva 2003/6/CE do Parlamento Europeu, com foco nos ilícitos do abuso de informação privilegiada e da manipulação de mercado, regulamento esse que foi importante instrumento relativo à matéria por uma cerca de uma década. ${ }^{71}$

Em 16 de abril de 2014, a União Europeia instituiu um quadro penal comum para punir crimes de abuso de mercado a partir do Regulamento

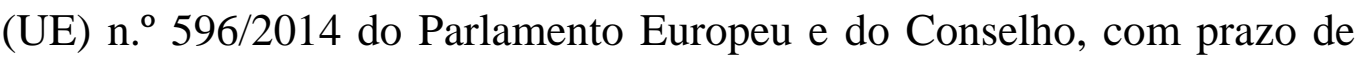
implementação dos Estados-membros até julho de 2016. O regulamento estabeleceu um quadro regulatório comum no âmbito de abuso de informação privilegiada, transmissão ilícita de informação privilegiada e

\footnotetext{
<https://ir.lawnet.fordham.edu/cgi/viewcontent.cgi?article=1554\&context=faculty_scholarship >. Acesso em 18/11/2018.

${ }^{70}$ ANTÓN, Antonio J. Monroy. Op. cit., p. 114.

71 WITTY Simon. The New EU Market Abuse Regulation. Disponível em <https://corpgov.law.harvard.edu/2016/06/17/the-new-eu-market-abuse-regulation/>. Acesso em $18 / 11 / 2018$.
} 
manipulação de mercado, além de definir medidas para evitar o abuso de mercado. Com isso, a União Europeia promove a integridade e a solidez dos seus mercados financeiros e reforça a confiança dos investidores.

Além disso, a partir de um quadro mais uniforme e sólido, é possível garantir aos participantes do mercado maior segurança jurídica e menos complexidade regulamentar, além de diminuir a possibilidade de arbitragem regulatória e assegurar a responsabilização no caso de tentativa de manipulação.

$\mathrm{O}$ artigo $12^{\circ}$ do Regulamento define as atividades englobadas no conceito de manipulação de mercado. Esse artigo é extenso e não taxativo. Engloba atividades como realizar operações, colocar ordens ou qualquer outra conduta que dê (ou seja idónea para dar) indicações falsas ou enganosas no que respeita à oferta, à procura ou ao preço de instrumentos financeiros, de um contrato de mercadorias à vista com eles relacionado ou de um produto leiloado baseado em licenças de emissão, ou possa assegurar o preço de um ou mais instrumentos a um nível anormal ou artificial. Inclui também divulgar informações através da comunicação social e da Internet que deem indicações falsas ou enganosas quanto à procura ou preço, transmitir informações falsas ou enganosos relativamente a um índice de referência.

No entanto, o Regulamento determina que a proibição de manipulação de mercado não se aplicará necessariamente às condutas definidas, desde que a pessoa que realizou a operação ou outra determinada ação comprove que tal ocorreu por razões legítimas e se encontra em conformidade com as práticas de mercado aceites.

O próprio Regulamento se encarrega de elencar o que seriam as práticas de mercado aceites a partir de alguns critérios, como, a título de exemplo, se a prática tiver um nível de transparência significativo para o mercado, ou um impacto positivo na liquidez e eficiência do mercado. São as autoridades competentes que identificam uma prática de mercado aceite com base nesses critérios, que possuem alto grau de subjetividade. 
Em seu artigo $32 .^{\circ}$, o Regulamento define o estabelecimento de mecanismos eficazes de comunicação de infrações ao Regulamento, que impeçam que os autores sofram retaliações, como a possiblidade de incentivos financeiros a denunciantes por parte dos Estados-Membros e proteção a retaliações no âmbito do local de trabalho para pessoas que comuniquem infrações.

“Artigo $32 .{ }^{\circ}$ Comunicação de infrações

1. Os Estados-Membros devem assegurar que as autoridades competentes estabelecem mecanismos eficazes para permitir a comunicação de infrações efetivas ou potenciais ao presente regulamento às autoridades competentes."

O Regulamento não se limita, portanto, em definir as condutas a serem condenadas em um quadro comum na União Europeia, mas delimita a necessidade de desenvolver mecanismos que permitam a efetiva identificação e repressão dos ilícitos.

\subsubsection{Diretiva 2014/57/EU}

Além disso, a Diretiva 2014/57/UE do Parlamento Europeu e do Conselho, de 16 de abril de 2014 define as sanções penais aplicáveis ao abuso de informação privilegiada e à manipulação de mercado.

$\mathrm{O}$ artigo $5^{\circ}$ trata especificamente da manipulação de mercado, novamente elencando de forma extremamente detalhada, mas não taxativa, as condutas passíveis de penalidade.

É notável que o tipo penal inclui o aspecto subjetivo do dolo, seguindo uma direção oposta da mudança realizada no artigo 27-C da lei 13.506/2017, que promoveu uma simplificação típica, expandido o tipo penal, uma vez que dispensou a necessidade de comprovação da finalidade de alterar o regular funcionamento do mercado.

No mais, a Diretiva impõe em seu artigo $7 .^{\circ}$ que os Estados-Membros implementem no seu ordenamento jurídico sanções criminais cujo limite 
máximo não poderá ser inferior a quatro anos para os crimes de abuso de informação privilegiada e manipulação de mercado. ${ }^{72}$

“Artigo 7. ${ }^{\circ}$ Sanções penais aplicáveis às pessoas singulares

2. Os Estados-Membros devem tomar as medidas necessárias para garantir que os crimes referidos nos artigos $3 .^{\circ}$ e $5 .^{\circ}$ sejam puníveis com uma pena máxima de prisão não inferior a quatro anos."

Apesar de não estabelecer uma pena mínima, o Regulamento define uma pena condizente com a prevista em nosso ordenamento jurídico, de um a oito anos, sendo a pena máxima maior que a demarcação de quatro anos.

Ressalta-se que, segundo Maíra Rocha Machado, cabe ao legislador comunitário tão somente exigir que sejam tomadas medidas adequadas, deixando aos Estados-membros a liberdade de implementar as sanções, devendo ser respeitado o limite mínimo estabelecido. ${ }^{73}$

É claro, portanto, o comprometimento da União Europeia no combate às práticas abusivas em seus mercados financeiros. Não só as autoridades administrativas passarão a dispor de mais poderes para investigar os abusos de mercado e impor sanções de milhões de euros, mas o quadro em comum instaurado em todo o continente permite que os responsáveis por abusos de mercado sejam dissuadidos pela perspectiva de poderem ser presos na União.

Cumpre ressaltar a previsão expressa, em ambos ordenamentos jurídicos, do cometimento de manipulação de mercado pela disseminação de informações falsas, o que não se verifica na legislação brasileira.

\footnotetext{
72 Europa aprova sanções penais comuns para crimes de abuso de mercado. Disponível em <https://www.jornaldenegocios.pt/mercados/detalhe/europa_aprova_sancoes_penais_comuns_para crimes_de abuso_de mercado>. Acesso em 18/11/2018.

${ }_{73}$ MACHADO, Maíra Rocha. Internacionalização do direito penal: a gestão de problemas internacionais por meio do crime e da pena. São Paulo: Editora 34, 2004. p. 118.
} 


\section{Conclusão}

O expressivo papel do mercado de capitais na sociedade pós-moderna, caracterizada pelo desenvolvimento tecnológico acelerado, acesso ilimitado à informação e livre circulação de capitais, aponta para a sua dinâmica célere.

Novos tipos de operações são estruturados, novos tipos de contratos de investimentos são criados e o mercado vai sofrendo constantes transformações. Naturalmente, a crescente tecnologia também dá ensejo a mecanismos cada vez mais sofisticados para subverter o regular funcionamento do mercado como forma de obter algum tipo de vantagem indevida.

A manipulação de mercado é um fenômeno antigo que se renova ao longo do tempo, aumentando a sua complexidade. É difícil imaginar um mercado sem agentes que tentarão manipulá-lo de alguma forma. Onde há grandes volumes de capital, há quem esteja disposto a lucrar a qualquer custo.

Portanto, é imprescindível o debate acerca da estrutura institucional de combate à manipulação, de modo a identificar as falhas para desenvolver mecanismos repressivos mais eficazes. A tecnologia pode ser usada como um importante aliado na repressão de ilícitos, contribuindo para o aprimoramento do controle das operações.

Os ilícitos de manipulação de mercado na esfera administrativa tiveram sua redação em 1979, com a ICVM n. ${ }^{\circ}$ 8/79, há quase quatro décadas. A amplitude da norma permite a sua adequação nas mais diversas situações, mas uma atualização se faz necessária para trazer simplificação e clareza aos ilícitos previstos, que atualmente se confundem entre si.

Normas mais precisas, dotadas de conceitos mais concretos e que proíbam expressamente aquilo que não deve ser feito no mercado de valores mobiliários têm um papel mais ativo na repressão da manipulação de mercado, dando maior segurança jurídica aos investidores.

Como citado anteriormente nesse trabalho, uma mudança positiva trazida pela Lei $\mathrm{n}^{\circ} 13.506 / 17$ foi o aumento significativo de patamar das 
multas aplicadas pela $\mathrm{CVM}$, de $\mathrm{R} \$ 500$ mil para $\mathrm{R} \$ 50$ milhões. $\mathrm{O}$ valor máximo anterior é irrisório para muitas companhias, compensando o ilícito e quase atuando como um incentivo ao seu cometimento.

Em relação ao Judiciário, a excessiva demora no julgamento nos crimes contra o mercado de capitais traz insegurança jurídica. Além disso, tais crimes são altamente técnicos e não há um grau de especialização tão profundo por parte do Judiciário, o que causa imprevisibilidade aos investidores.

Assim, a cooperação entre o Judiciário e a CVM se faz extremamente necessária. Os órgãos já atuaram em ações conjuntas, mas a interação entre a esfera penal e administrativa deve ser ampla, provendo auxílio aos magistrados para julgar um tema tão específico. Além disso, uma melhor comunicação permite uma melhor compreensão das decisões no mercado de capitais.

A harmonização entre os sistemas legais reguladores do mercado de capitais, pelo aumento dos fluxos econômicos em escala global, também assume grande importância no combate à manipulação de mercado.

Por fim, a expectativa desse trabalho é incentivar o debate em relação ao tema, tão pouco explorado, sem nenhuma pretensão de esgotá-lo, mas trazendo à reflexão a necessidade de constante adequação do Direito às mudanças da sociedade. 


\section{Referências bibliográficas}

AMENDOLARA, Leslie. Fundamentos e Objetivos da Regulamentação do Sistema de Informação de Sociedades que fazem Ofertas Públicas. In: VII Congresso Argentino de Derecho Societario y III Congresso Iberoamericano de Derecho Societario y de la Empresa. La Sociedad Comercial ante El tercer milênio, Buenos Aires, 1998.

ANTÓN, Antonio J. Monroy. El delito de abuso de información privilegiada em el mercado de valores. Madrid Dijusa, 2006.

ARAGÃO, Alexandre Santos de. Agências Reguladoras e a Evolução do Direito Administrativo Econômico. Rio de Janeiro: Forense. 2002.

BALTAZAR JUNIOR, José Paulo. Crimes Federais. 10ª ed. São Paulo: Saraiva, 2015.

BELEZA, Teresa, Direito Penal, 2. ${ }^{\circ}$ Vol. Lisboa: AAFDL, 1983.

BITTENCOURT, Cezar Roberto. Tratado de direito penal econômico. São Paulo: Saraiva, vol. I, 2016.

CARVALHOSA, Modesto; EIZIRIK, Nelson. A nova Lei das sociedades anônimas. São Paulo: Saraiva, 2002.

COMISSÃO DE VALORES MOBILIÁRIOS. O mercado de valores mobiliários brasileiro. $3^{\mathrm{a}}$ ed. Rio de Janeiro: Comissão de Valores Mobiliários.

CORNELL LAW SCHOOL. Securities Exchange Act of 1934. Disponível em <https://www.law.cornell.edu/wex/securities_exchange_act_of_1934>. Acesso em 18/11/2018. 
CVM condena por manipulação de preço. Disponível em <http://www.cvm.gov.br/noticias/arquivos/2016/20161208-2.html>. Acesso em 18/11/2018.

CVM condena Rafael Ferri por manipulação de ações da Mundial. Disponível em <https://exame.abril.com.br/mercados/cvm-condena-rafaelferri-por-manipulacao-de-acoes-da-mundial/> . Acesso em 18/11/2018.

CVM e MPF obtêm primeira condenação penal por manipulação de mercado do Brasil. $\quad$ Disponível em <http://www.cvm.gov.br/noticias/arquivos/2016/20161111-2.html>. Acesso em 18/11/2018.

CVM e MPF prorrogam Termo de Cooperação Técnica. Disponível em <http://www.cvm.gov.br/noticias/arquivos/2018/20180508-2.html>. Acesso em 18/11/2018.

DUBEUX, Julio Ramalho. A Comissão de Valores Mobiliários e os principais instrumentos regulatórios do mercado de capitais brasileiro. Porto Alegre: Sergio Antonio Fabris, 2006.

EIZIRIK, Nelson. Aspectos modernos do Direito Societário. Rio de Janeiro: Renovar. 1992.

EIZIRIK, Nelson et atl. Mercado de Capitais Regime Jurídico. $2^{\mathrm{a}}$ Ed, Rio de Janeiro: Renovar, 2008.

Europa aprova sanções penais comuns para crimes de abuso de mercado. Disponível em $<$ https://www.jornaldenegocios.pt/mercados/detalhe/europa_aprova_sancoe s_penais_comuns_para_crimes de_abuso_de_mercado $>$. Acesso em $18 / 11 / 2018$ 
FCA fines US based oil trader US $\$ 903 \mathrm{~K}$ for Market manipulation $<$ https://www.fca.org.uk/news/press-releases/fca-fines-us-based-oil-traderus-903k-market-manipulation>. Acesso em 18/11/2018.

FRAGOSO, Heleno Cláudio. Lições de Direito Penal: a Nova Parte Geral. $11^{\mathrm{a}}$ ed., revista por Fernando Fragoso, Rio de Janeiro, Forense, 1987.

Guidelines on systems and controls in an automated trading environment for trading platforms, investment firms and competent authorities. Disponível em <https://www.esma.europa.eu/sites/default/files/library/2015/11/2011456_0.pdf>. Acesso em 18/11/2018.

JESUS, Damásio E. de. Código Penal anotado, São Paulo, Saraiva, 2000

JOHNSTONE, Peter. New Regulatory Architecture, in: European Financial Services Law, 1999.

KUMPEL, Siegfried. Direito do mercado de capitais - do ponto de vista do direito europeu, alemão e brasileiro. Rio de Janeiro: Renovar, 2007.

MACHADO, Maíra Rocha. Internacionalização do direito penal: a gestão de problemas internacionais por meio do crime e da pena. São Paulo: Editora 34, 2004.

OSÓRIO, Fábio Medina, Direito Administrativo Sancionador, $4^{\mathrm{a}}$ ed. São Paulo: Editora Revista dos Tribunais, 2011.

PAMPLONA, Nicola. CVM multa acusados de nova forma de manipulação do mercado. Disponível em $<$ https://www1.folha.uol.com.br/mercado/2018/03/cvm-multa-acusados-denova-forma-de-manipulacao-do-mercado.shtml>. Acesso em 18/11/2018. 
PARENTE, Norma. A Regulação e o desenvolvimento do Mercado de Capitais. Revista de Direito Bancário do Mercado de Capitais e da Arbitragem. São Paulo: Revista dos Tribunais, n. ${ }^{\circ}$ 18, out-dez/2002. p. 247.

PARENTE, Norma. Tratado de Direito Empresarial. Vol. 6. Rio de Janeiro: Revista dos Tribunais, 2018.

PIMENTA, Guilherme. Spoofing: nova forma de manipular o mercado de ações. Disponível em <https://www.jota.info/justica/spoofing-nova-formade-manipular-o-mercado-de-acoes-03092017> . Acesso em 18/11/2018.

PINTO, Frederico de Lacerda da Costa. O novo regime de crimes e contraordenações no código dos valores mobiliários. Coimbra: Almedina, 2000.

PRATES, Homero. Atos simulados e atos em fraude à lei. São Paulo: Freitas Bastos.

REIS, Tiago. SEC: Saiba O Que Faz Essa Agência Dentro Do Mercado De Valores Dos EUA. $\quad$ Disponível em $<$ https://www.sunoresearch.com.br/artigos/sec/ > Acesso em 18/11/2018.

RUIZ, Daniel Entrena. El empleo de información privilegiada em el mercado de valores: un estudio de su régimen administrativo sancionador. Navarra: Editorial Arazandi, 2006.

SANCTIS, Fausto Martin de. Punibilidade no Sistema Financeiro Nacional: Tipos penais que tutelam o sistema financeiro nacional, incluindo o mercado de capitais. Campinas: Millennium, 2003.

SANTOS, Alexandre Pinheiro dos; WELLISCH, Julya Sotto Mayor; BARROS, José Eduardo Guimarães. Mercado de Capitais. São Paulo: Saraiva, 2012. 
SIMÕES, Pedro. Insider trading e crime de manipulação de mercado: reflexos da nova lei. Disponível em <https://www.jota.info/opiniao-eanalise/artigos/insider-trading-e-crime-de-manipulacao-de-mercadoreflexos-da-nova-lei-27012018>. Acesso em 18/11/2018.

SUNDFELD, Carlos Ari. Direito Econômico Brasileiro, $1^{\mathrm{a}}$ ed., $2^{\mathrm{a}}$ tiragem. São Paulo: Malheiros.

THEL, Steve. Taking Section 10(b) Seriously: Criminal Enforcement of SEC Rules Disponível

em $<$ https://ir.lawnet.fordham.edu/cgi/viewcontent.cgi?article=1554\&context=f aculty_scholarship>. Acesso em 18/11/2018.

TORRES, Marcos José Rodrigues; CUTER, Julio Cesar; CALABRÓ, Luiz Felipe Amaral. Monitoração de ofertas - Spoofing e Layering. Disponível em

http://www.bsmautorregulacao.com.br/assets/file/noticias/Monitoraca_Ofertas.pdf >. Acesso em 18/11/2018.

US SECURITIES AND EXCHANGE COMISSION. The Laws That Govern the Securities Industry. Disponível em < lawsshtml.html\#secexact1934>. Acesso em 18/11/2018.

VEIGA, Alexandre Brandão da. Crime de manipulação, defesa e criação de mercado. Coimbra: Almedina, 2001.

WITTY Simon. The New EU Market Abuse Regulation. Disponível em $<$ https://corpgov.law.harvard.edu/2016/06/17/the-new-eu-market-abuseregulation/>. Acesso em 18/11/2018.

YAZBEK, Otávio. Regulação do mercado financeiro e de capitais. Rio de Janeiro: Elsevier, 2009. 